$10-2017$

\title{
Metal Substitution and Solvomorphism in Alkylthiolate-Bridged Zn3 and HgZn2 Metal Clusters
}

Madeline R. Hallinger

Alison C. Gerhard

Mikhaila D. Ritz

et al.

John C. Poutsma

See next page for additional authors

Follow this and additional works at: https://scholarworks.wm.edu/aspubs

Part of the Chemistry Commons 
Authors

Madeline R. Hallinger, Alison C. Gerhard, Mikhaila D. Ritz, et al., John C. Poutsma, and Robert D. Pike 


\section{Metal Substitution and Solvomorphism in Alkylthiolate-Bridged $\mathrm{Zn}_{3}$ and $\mathrm{HgZn}_{2}$ Metal Clusters}

Madeline R. Hallinger, ${ }^{\dagger, \S}$ Alison C. Gerhard, ${ }^{\dagger}$ Mikhaila D. Ritz, $^{\dagger, \|}$ Joshua S. Sacks, $^{\dagger}$ John C. Poutsma, ${ }^{\dagger}$ Robert D. Pike, ${ }^{\dagger}$ Lukasz Wojtas, ${ }^{\dagger}$ and Deborah C. Bebout* ${ }^{\dagger} \dagger$

${ }^{\dagger}$ Department of Chemistry, College of William \& Mary, P.O. Box 8795, Williamsburg, Virginia 23188, United States

${ }^{\ddagger}$ Department of Chemistry, University of South Florida, 4202 E. Fowler Avenue, CHE 205, Tampa, Florida 33620, United States

\section{Supporting Information}

ABSTRACT: The impact of substituting $\mathrm{Hg}(\mathrm{II})$ for $\mathrm{Zn}(\mathrm{II})$ in a thiolate-bridged trinuclear cluster with parallels to a metallothionein metal cluster was investigated. A new solvomorph of $\left[\mathrm{Zn}(\mathrm{ZnL})_{2}\right]\left(\mathrm{ClO}_{4}\right)_{2}$ (1) $(\mathrm{L}=\mathrm{N}$-(2-pyridylmethyl)- $\mathrm{N}$-(2-(ethylthiolato)-amine) and five solvomorphs of a new compound $\left[\mathrm{Hg}(\mathrm{ZnL})_{2}\right]\left(\mathrm{ClO}_{4}\right)_{2}(2)$ were characterized by single-crystal X-ray crystallography. The interplay of hydrogen bonding and aromatic-packing interactions in producing lamellar, 2D lamellar, and columnar arrangements of complex cations in the crystalline state is discussed. Both variable temperature proton nuclear magnetic resonance and electrospray ion-mass spectrometry (ESI-MS) suggest that the

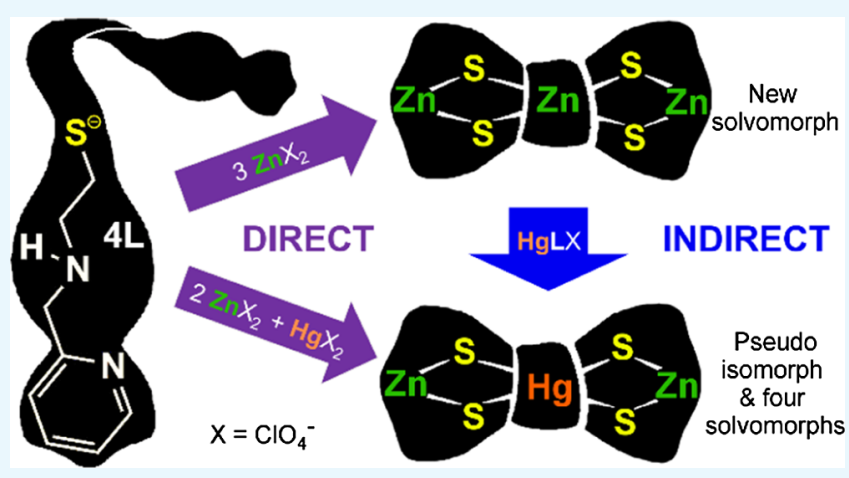
complex ions of $\mathbf{1}$ and $\mathbf{2}$ are the predominant solution species at moderate concentrations. ESI-MS was also used to monitor differences in metal ion redistribution as $\mathbf{1}$ was titrated with $\mathrm{Hg}\left(\mathrm{ClO}_{4}\right)_{2}$ and $\left[\mathrm{HgL}\left(\mathrm{ClO}_{4}\right)\right]$. These studies document the facile replacement of $\mathrm{Zn}$ (II) by $\mathrm{Hg}(\mathrm{II})$ with the preservation of the overall structure in thiolate-rich clusters.

\section{INTRODUCTION}

The fascinating interplay of structure and function has motivated continuous efforts to prepare synthetic complexes inspired by metalloproteins. Significant advances in our understanding of protein/metal binding sites have come from the investigation of small synthetic complexes. ${ }^{1-7}$ Although small metal/ligand complexes reproduce only a small fraction of the information encoded within the holoprotein framework, they serve as milestones toward more elaborate models. ${ }^{8,9}$

Multimetallic proteins present especially complex synthetic challenges. ${ }^{6,10-14}$ The ubiquitous multimetallic metallothionein protein family has a variety of exceptional properties, inviting further study. ${ }^{15}$ Unusual structural characteristics of metallothioneins include low homology primary sequences with nearly $30 \%$ cysteine residues and tertiary structures varying with metal occupancy. Metallothioneins are multifunctional and commonly associated with $\mathrm{Zn}(\mathrm{II})$ and $\mathrm{Cu}(\mathrm{I})$ homeostasis as well as removal of xenobiotic $\mathrm{Cd}(\mathrm{II})$ and $\mathrm{Hg}(\mathrm{II})$ metal ions. ${ }^{16}$ The best characterized forms of metallothionein have cysteine thiolate-bridged three- and four-metal clusters. ${ }^{17-20}$ However, under physiological conditions, a wide variety of homo- and heterometallic variants coexist with dynamical conformations. ${ }^{16,21-23}$ The spectroscopic techniques commonly used to monitor the metallothionein metal ion exchange have provided limited information about structural changes to the metal clusters. ${ }^{24}$ Significantly, despite strong association with
$\mathrm{Hg}$ (II) detoxification, there are no crystal structures of metallothionein bound to $\mathrm{Hg}$ (II).

Synthetic approaches to modeling the metal clusters of metallothionein have commonly involved deprotonated monoand dialkylthiolates. ${ }^{25}$ Self-assembly reactions between thiolates and $\mathrm{d}^{10}$ metal ions invariably lead to a complex solution milieu from which individual clusters must be crystallized for a detailed characterization. Although the metal clusters of metallothionein are predominantly cysteine-ligated, there is evidence from nuclear magnetic resonance (NMR), ${ }^{26,27}$ extended X-ray absorption fine structure (EXAFS), ${ }^{28}$ and histidine modification analyses ${ }^{29}$ for histidine ligation. Our approach to expanding isolable metallothionein-like $\mathrm{d}^{10}$ metal ion clusters has focused on using multidentate mixed donor ligands, incorporating thiolates and simple nitrogen donors as synthetic counterparts of the bridging and nonbridging ligands, respectively. In a recent work, we used tridentate ligand $\mathrm{N}$-(2pyridylmethyl)- $\mathrm{N}$-(2-(ethylthiolato)amine) (LH; Figure 1) to prepare a novel complex with a bicyclo[3.3.3] $\mathrm{Hg}_{5} \mathrm{~S}_{6}$ core. ${ }^{30} \mathrm{On}$ the basis of the electrospray ion-mass spectrometry (ESI-MS) evidence, this complex crystallized from a solution containing complexes with a variety of $\mathrm{Hg} / \mathbf{L}$ stoichiometries, a process

Received: July 28, 2017

Accepted: September 21, 2017

Published: October 5, 2017 
<smiles>[2H]C([2H])([2H])C(C)(C)NC(C)(C)c1nc(C)c(C)c(C)c1C</smiles>

Figure 1. LH with proton-labeling and highlighted $\mathrm{NC}_{2} \mathrm{NC}_{2} \mathrm{~S}$ synthon.

analogous to the physiological sequestration of $\mathrm{Hg}$ (II) in the kidneys by metallothionein.

In this work, our focus shifted toward investigating mixed $\mathrm{HgZn}$ clusters as synthetic models of the metal substitution occurring when Zn-metallothionein is confronted by the heavier congener. There are only a modest number of structurally characterized mixed $\mathrm{HgZn}$ complexes, and to the best of our knowledge, none involving alkylthiolate bridges. ${ }^{31}$ Furthermore, the only structurally characterized trinuclear zinc complexes containing $\mathrm{Zn}$ (alkylthiolato) ${ }_{4}$ analogs of the zinc coordination reported for metal-saturated metallothionein have incorporated a single ligand with an $\mathrm{NC}_{2} \mathrm{NC}_{2} \mathrm{~S}$ synthon in common with $\mathbf{L}^{32-34}$ or multiple ligands. ${ }^{31}$ Known zinc complexes of $\mathbf{L}$ include $\left[\mathrm{Zn}(\mathrm{ZnL})_{2}\right]\left(\mathrm{BF}_{4}\right)_{2} \cdot 2 \mathrm{H}_{2} \mathrm{O}\left(\mathbf{1}^{\prime} \mathbf{a}\right)^{32}$ and $\left[\mathrm{Zn}(\mathrm{ZnL})_{2}\right]\left(\mathrm{ClO}_{4}\right)_{2} \cdot 2 \mathrm{CH}_{3} \mathrm{OH}(\mathbf{1 b}) .^{33}$ The $\left[\mathrm{Zn}(\mathrm{ZnL})_{2}\right]^{2+}$ core of these complexes is shown schematically in Figure 2. The

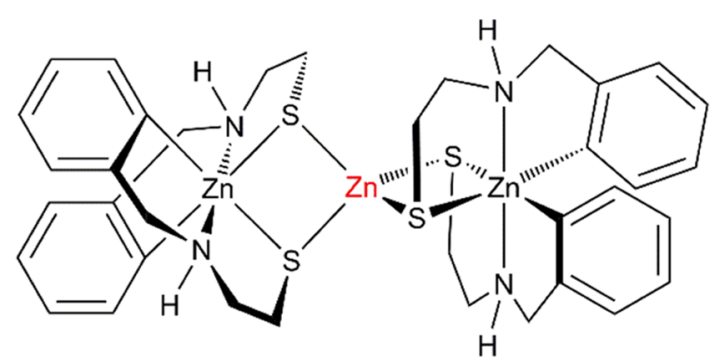

Figure 2. Tetrahedral site targeted for replacement in the $[\mathrm{Zn}$ $\left.(\mathrm{ZnL})_{2}\right]^{2+}$ core.

central position was targeted for replacement by $\mathrm{Hg}(\mathrm{II})$. Significantly, the core cluster offered hydrogen bond donors and aromatic rings for stabilizing intermolecular interactions. In addition to preparing a new acetonitrile solvomorph of the zinc cluster (1c), solvomorphs of $\left[\mathrm{Hg}(\mathrm{ZnL})_{2}\right]\left(\mathrm{ClO}_{4}\right)_{2}(2)$ in three different crystal systems were prepared by either direct selfassembly or indirectly from 1 and $\left[\mathrm{HgLClO}_{4}\right]$ (3). The new solvomorphs were characterized by single-crystal X-ray diffraction, and their differences in packing are discussed with respect to their relevance to metallothionein. In addition, variable temperature proton NMR and ESI-MS are used to analyze solution speciation and gain insight regarding the metal substitution process.

\section{RESULTS AND DISCUSSION}

2.1. Complex Synthesis. Deprotonated LH has been reported to form complex cations of composition $\left[\mathrm{Zn}_{3} \mathbf{L}_{4}\right]^{2+}$, with counterions generally described as noncoordinating $\left(\mathrm{ClO}_{4}^{-}, \mathrm{BF}_{4}^{-}\right.$, and $\left.\mathrm{NO}_{3}^{-}\right)$irrespective of the stoichiometric ratio of the reactants and in different solvents. ${ }^{32}$ Established methods were used to prepare the initial precipitate with composition $\left[\mathrm{Zn}_{3} \mathrm{~L}_{4}\right]\left(\mathrm{ClO}_{4}\right)_{2}$ (1) from water. Recrystallization of 1 from acetonitrile/toluene by slow evaporation provided the new solvate $\left[\mathrm{Zn}(\mathrm{ZnL})_{2}\right]\left(\mathrm{ClO}_{4}\right)_{2} \cdot 2 \mathrm{CH}_{3} \mathrm{CN}(\mathbf{1 c})$.
Both direct and indirect methods of preparing $\left[\mathrm{Hg}\left(\mathrm{ZnL}_{2}\right)_{2}\right]$ $\left(\mathrm{ClO}_{4}\right)_{2}(2)$ were investigated (Figure 3). In the direct method

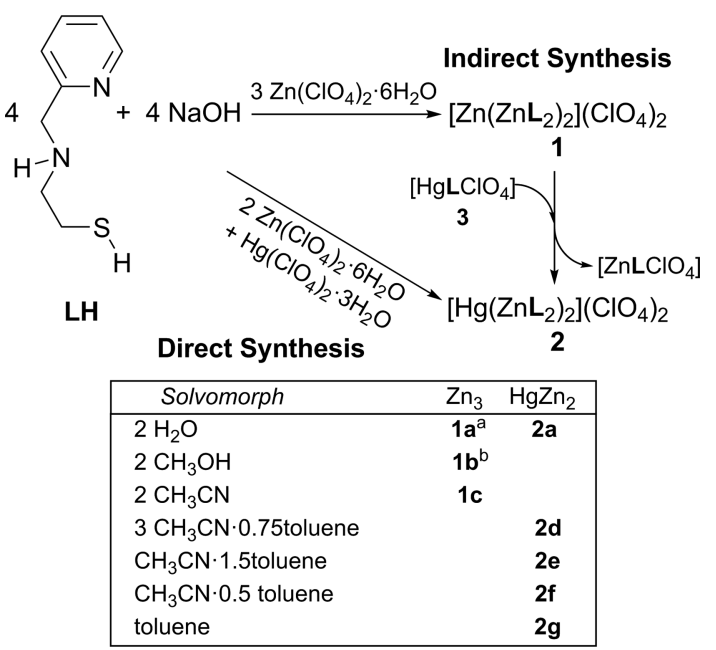

Figure 3. Syntheses of $\mathbf{1}$ and $\mathbf{2}$ and solvomorphs studied. ${ }^{\mathrm{a}}$ Ref $32 .{ }^{\mathrm{b}}$ Ref 33.

for preparing mixed $\mathrm{HgZn}$ complexes of $\mathbf{L}$ by self-assembly, the components were mixed in various mole ratios. An initial precipitate of $\left[\mathrm{HgZn}_{2} \mathrm{~L}_{4}\right]\left(\mathrm{ClO}_{4}\right)_{2}(2)$ with variable amounts of water was prepared by adding an aqueous solution containing a 1:2 ratio of $\mathrm{Hg}\left(\mathrm{ClO}_{4}\right)_{2} / \mathrm{Zn}\left(\mathrm{ClO}_{4}\right)_{2}$ to an aqueous solution of sodium hydroxide deprotonated $\mathbf{L H}$ in a $3: 4$ metal/ligand stoichiometric ratio. Recrystallization of precipitate 2 by slow evaporation from acetonitrile/toluene initially produced thin colorless plates of solvate $\mathbf{2} \cdot 2 \mathrm{H}_{2} \mathrm{O}(\mathbf{2 a})$ in a low yield. Brand and Vahrenkamp previously reported isolation of $1 \mathrm{a}$ from methanol/water and spectroscopic characterization, but no crystallographic characterization. ${ }^{32}$ Consistent with Ostwald's step rule for polymorph recrystallization, ${ }^{35}$ further crystal growth from the mother liquor of $\mathbf{2 a}$ produced solvomorphs with water replaced by higher concentration solvents. Large, colorless prisms of mixed solvate $2 \cdot 3 \mathrm{CH}_{3} \mathrm{CN} \cdot 0.75$ toluene $(\mathbf{2 d})$ were isolated next. Additional crystal growth from the mother liquor of $2 \mathrm{~d}$ provided very fine colorless needles of $2 \cdot \mathrm{CH}_{3} \mathrm{CN}$. 1.5 toluene $(\mathbf{2 e})$. Both the mixed solvates were unstable to the loss of the solvent. In a subsequent preparation, these three solvomorphs crystallized concurrently during slow evaporation (Figure S3a). Polymorphs $2 \mathbf{d}$ and $2 \mathrm{e}$ were also recovered from the slow diffusion of an acetonitrile solution of $\mathbf{2}$ into toluene. In addition, we attempted to prepare an isomorph of acetonitrile solvate $1 \mathrm{c}$ by slow diffusion of ether into an acetonitrile solution of precipitate $\mathbf{2 a}$. However, the colorless needles produced appeared to be a solvomorphic variant of $\mathbf{2 d}$ in which toluene is replaced by badly disordered acetonitrile and ether (2h; Figure S4). Limited additional direct syntheses with alternative $\mathrm{Hg} / \mathrm{Zn} / \mathrm{L}$ ratios did not provide materials with promising diffraction, elemental analysis, or NMR.

To prepare 2 indirectly, precipitated $\left[\mathrm{HgL}\left(\mathrm{ClO}_{4}\right)\right]$ (3) was used as the source of $\mathrm{Hg}(\mathrm{II})$ because ESI-MS studies suggested insignificant formation of 2 when $1-3$ equiv of $\left[\mathrm{Hg}\left(\mathrm{ClO}_{4}\right)_{2}\right]$ was added to $\mathbf{1}$ (vide infra). Two additional solvates of $\mathbf{2}$ were prepared indirectly by slow evaporation from an equimolar solution of 1 and 3 in acetonitrile/toluene. Initially, marginal quality plates of $2 \cdot \mathrm{CH}_{3} \mathrm{CN} \cdot 0.5$ toluene (2f) and $\mathbf{1 c}$ formed evaporatively in trace amounts along with nondiffracting solids 
(Figure S3b). Plates of $\mathbf{1 c}$, higher quality crystals of $\mathbf{2 f}$, as well as plates of $\mathbf{2}$.toluene $(\mathbf{2 g})$ were produced concurrently and in low yield by slow diffusion of an equimolar acetonitrile solution of 1 and 3 into toluene.

2.2. Single-Crystal Structures. Acyclic trinuclear thiolatebridged zinc(II) clusters with distorted tetrahedral $\mathrm{S}_{4}$ central $\mathrm{Zn}$ (II) coordination and meridional (cis, trans, and cis) $\mathrm{N}_{2} \mathrm{~N}_{2}^{\prime} \mathrm{S}_{2}$ octahedral terminal $\mathrm{Zn}$ (II) coordination (Figure 2) are one of several well-established coordination motifs for tridentate ligands containing a 2-((2-aminoethyl)amino)ethanethiolato moiety. ${ }^{31}$ The octahedral sites of these complexes have helical chirality (Figure 4). The characterized solvomorphs of $\mathbf{1}$ and $\mathbf{2}$
$\Delta \Lambda$

meso

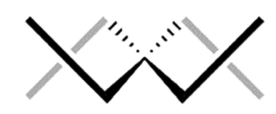

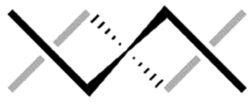

$\Delta \Delta$

Diastereomers
Figure 4. Skew line depiction of $\mathrm{M}(\mathrm{ML})_{2}$ coordination environment stereochemistry.

exhibited differences in hydrogen bonding, aromatic interactions, and packing motifs, which are somewhat analogous to the established ability of metallothionein to adopt multiple conformations. Hence, there was more incentive for an indepth analysis of intermolecular interactions than in most structural studies of coordination compounds. ${ }^{36}$

2.2.1. Unit Cell Contents, Symmetry, and Hydrogen Bonding. The two known pseudopolymorphs of $\mathrm{Zn}_{3} \mathbf{L}_{4}{ }^{2+}$ were isolated in tetragonal $I \overline{4}\left(\left[\mathrm{Zn}(\mathrm{ZnL})_{2}\right]\left(\mathrm{BF}_{4}\right)_{2} \cdot 2 \mathrm{H}_{2} \mathrm{O}\right.$, $\left.\mathbf{1}^{\prime} \mathbf{a}\right)^{32}$ and triclinic $P \overline{1}\left(\left[\mathrm{Zn}(\mathrm{ZnL})_{2}\right]\left(\mathrm{ClO}_{4}\right)_{2} \cdot 2 \mathrm{CH}_{3} \mathrm{OH}, \mathbf{1 b}\right)^{33}$ crystal systems. Complex $\mathbf{1}^{\prime}$ a was composed of two similar independent trinuclear complexes, with $S_{4}$ symmetry imposed by the crystal system and meso-octahedral stereochemistry. By contrast, $\mathbf{1} \mathbf{b}$ consisted of a pair of inversion-related pseudomeso complexes. Stereochemistry and geometric parameters of these trimetallic cores are summarized in Table 1 for comparison with the new compounds. To preserve crystal integrity, data collection for new compounds was started at 100 $\mathrm{K}$ promptly after removal of the mother liquor. With the exception of $\mathbf{1 b}$, all four amino protons of each trimetallic complex ion are involved in hydrogen bonding. The diversity of hydrogen bond patterns observed is reminiscent of the elusive role of the metallothionein interdomain linker and limited success characterizing interdomain contacts. ${ }^{37,38}$

New acetonitrile solvomorph 1c (Figure 5a) crystallizes in the orthorhombic space group $P n a 2_{1}$ with four asymmetric units in each unit cell. The asymmetric unit contains one pseudo-meso $\left[\mathrm{Zn}(\mathrm{ZnL})_{2}\right]^{2+}$, two well-ordered perchlorates, and two acetonitrile solvent molecules. One perchlorate bridges $\mathrm{N}(4)$ and $\mathrm{N}(8)$ of twofold screw related molecules through hydrogen bonding. This forms a molecular chain structure that zigzags along the $b$ axis and undulates infinitely along the $c$ axis (Figure $5 \mathrm{~b}$ and Table 2 ). The remaining amino hydrogens of the complex ion are hydrogen-bonded to either $\mathrm{O}(1)$ of the second perchlorate or $\mathrm{N}(10)$ of an acetonitrile. The $\mathrm{Zn}_{3} \mathrm{~S}_{4}$ core of the complex is somewhat compressed relative to the known solvomorphs, with the smallest nearest neighbor and end-toend $\mathrm{Zn} \cdots \mathrm{Zn}$ separations (Table 1 ).

Complex 2 a crystallized in the tetragonal space group $I \overline{4}$ and proved to be a pseudoisomorph of 1'a with mercury and perchlorate substituted for the central zinc and tetrafluoroborate, respectively. The asymmetric unit of 2 a contains two

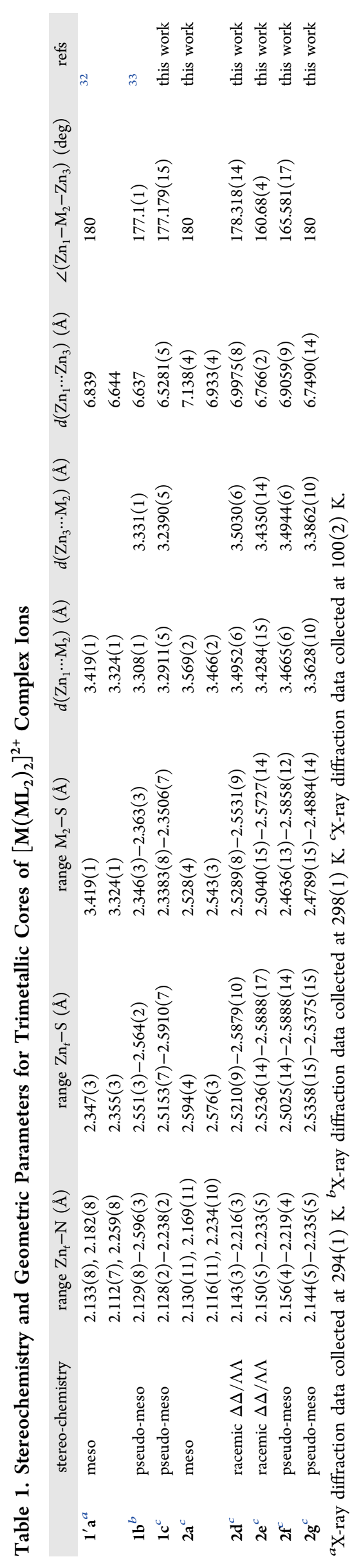



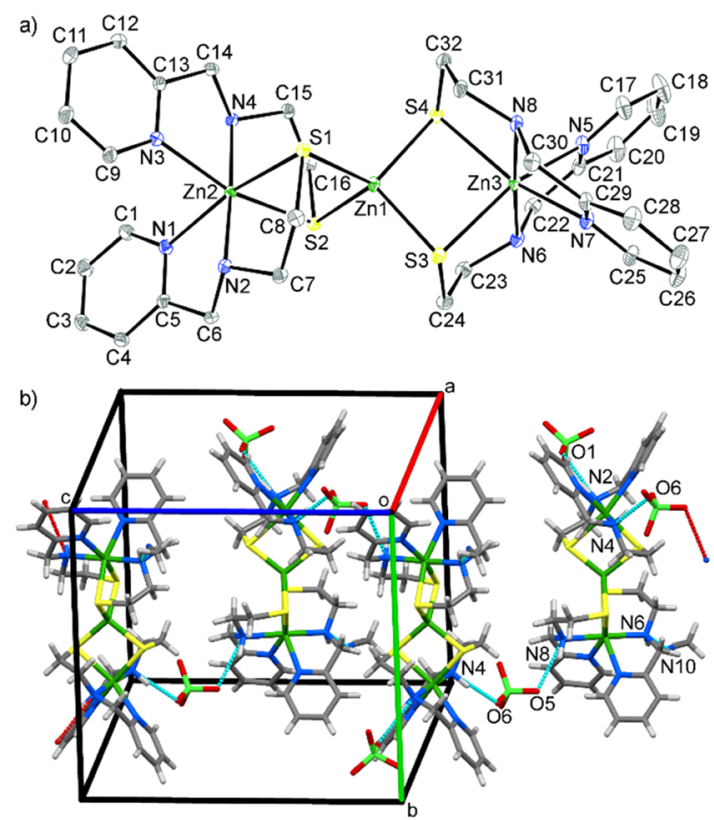

Figure 5. (a) Thermal ellipsoid drawing for the complex ion of 1c showing the crystallographic numbering scheme. Thermal ellipsoids are shown at $50 \%$ probability. (b) Hydrogen-bonding chain diagram (nonparticipating acetonitrile omitted). Hydrogen bonds are indicated by dashed cyan lines.

one-quarter $\left[\mathrm{Hg}(\mathrm{ZnL})_{2}\right]^{2+}$ (Figure 6a) complex ions, one disordered perchlorate modeled over two positions, and a water solvent molecule. The independent heterometallic complex ions of $\mathbf{2 a}$ are more similar to each other than the complex ions of the other two solvomorphs of 2 reported (Figure 7). The independent molecules of $\mathbf{2 a}$ and $\mathbf{1}^{\prime} \mathbf{a}$ are structurally comparable, and the locations for the complex ion, counterion, and solvent components of the asymmetric unit are similar (Figure 8). However, the orientation of the water molecule is shifted, possibly as a result of differences in hydrogen bonding. Both perchlorate positions have two oxygens involved in hydrogen bonding, one with the $\mathrm{N}(2)$ hydrogen and one with a water hydrogen. The water also acts as a hydrogen bond donor with $S(1)$ of one independent molecule and a hydrogen bond acceptor from $\mathrm{N}(2)$ resulting in a three-dimensional network (Figure 6b, Table 2).

Heterosolvate $\mathbf{2 d}$ crystallized in the monoclinic space group $\mathrm{C} 2 / \mathrm{c}$ with eight asymmetric units in each unit cell. The complex ion is present as a racemic mixture of diastereomers $(\Delta \Delta / \Lambda \Lambda)$. The asymmetric unit contains one complex ion (Figure 9a), one ordered perchlorate, one perchlorate disordered over two positions with unequal occupancy, a mixture of solvent molecules including three disordered acetonitriles, one of which sits on a special position, and three-quarters of a toluene coincident with some of the disordered acetonitrile. The perchlorates are each hydrogen-bonded to two amine nitrogens, forming a series of $\mathrm{N}(4)-\mathrm{N}(8)$ and $\mathrm{N}(2)-\mathrm{N}(6)$ hydrogen bond bridges that give rise to a hydrogen-bonded ribbon of pairwise alternating diastereomers parallel to the crystallographic ac plane (Figure $9 \mathrm{~b}$ and Table 2).

Mixed solvate $2 \mathrm{e}$ crystallized in the triclinic space group $P \overline{1}$. The complex ion is present as a racemic mixture of diastereomers $(\Delta \Delta / \Lambda \Lambda)$. The ordered parts of the asymmetric unit include a single diastereomer of the complex ion (Figure 10a), one well-ordered perchlorate, and one-half of a well- ordered toluene sitting on a special position. The disordered parts of the asymmetric unit include a perchlorate, an acetonitrile, and a toluene, each modeled over two positions with unequal occupancy. The perchlorates are each hydrogenbonded to two amine nitrogens, forming a series of $\mathrm{N} 1-\mathrm{N} 3$ and N5-N7 hydrogen bond bridges that give rise to infinite hydrogen-bonded ribbons parallel to the crystallographic $a b$ plane (Figure 10b and Table 2). The complex ion has the greatest degree of core puckering among the trinuclear complexes investigated, with a $\mathrm{Zn}(1) \cdots \mathrm{Hg}(1) \cdots \mathrm{Zn}(1)$ angle of 160.68(4) (Table 1).

Mixed solvate $\mathbf{2} \mathbf{f}$ also crystallized in the triclinic space group $P \overline{\mathbf{1}}$. The asymmetric unit of $\mathbf{2} \mathbf{f}$ contains one pseudo-meso $(\Delta \Lambda)$ $\left[\mathrm{Hg}(\mathrm{ZnL})_{2}\right]^{2+}$ (Figure 11a), two well-ordered perchlorates, an acetonitrile, and half a toluene. The toluene is located on an inversion center between the central $\mathrm{Hg}$ of two complex cations. Infinite zigzag chains of individual enantiomers are formed parallel to the crystallographic $a b$ plane through perchlorate-mediated hydrogen bonding of $\mathrm{N}(4)$ and $\mathrm{N}(8)$ (Figure $11 \mathrm{~b}$ and Table 2). Similar hydrogen-bonded chains are formed in $\mathbf{1 b}$. A pair of oxygen from the second perchlorate are hydrogen-bonded to the $\mathrm{N}(2)$ hydrogen, and an acetonitrile is hydrogen-bonded to the $\mathrm{N}(6)$ hydrogen.

Complex $2 \mathrm{~g}$ crystallized in the monoclinic space group $\mathrm{P} 2 / \mathrm{n}$ with a crystallographic $C_{2}$ axis running through the three metal ions of the complex ion (Figure 12 and Table 1). The asymmetric unit contains one half of the pseudo-meso $\Delta \Lambda$ complex ion (Figure 12a), a well-ordered perchlorate, and a badly disordered toluene sitting on a special position. The perchlorate ions bridge $\mathrm{N}(2)$ and $\mathrm{N}(4)$ of the inversion-related complexes by a pair of hydrogen bonds, forming infinite ribbons parallel to the (101) crystal plane (Figure $12 \mathrm{~b}$ and Table 2). The $\mathrm{HgZn}_{2} \mathrm{~S}_{4}$ core of the complex is slightly more compact than the other solvomorphs of 2, with smaller intramolecular $\mathrm{Zn} \cdots \mathrm{Hg}$ and $\mathrm{Zn} \cdots \mathrm{Zn}$ separations despite the $\mathrm{Zn}(1)-\mathrm{Hg}(1)-\mathrm{Zn}(2)$ angle of $180^{\circ}$ (Figure 7 and Table 1).

2.2.2. Interactions between Pyridyl Ends. One of the defining features of metallothioneins is the absence of aromatic amino acids other than histidine involved in metal coordination. As a result, aromatic-stacking interactions are absent, helping to ensure the metal dependence of structure acquisition. By contrast, the roughly orthogonal meridional (cis, trans, and cis) octahedral $\mathrm{Zn}$ (II) termini of $\mathbf{1}$ and $\mathbf{2}$ are conducive to supramolecular structures through synergistic offset face-to-face $\pi-\pi$ (OFF) and edge-to-face $\pi-\sigma$ (EF) interactions. ${ }^{39,40}$ Although the $\mathrm{N}-\mathrm{Zn}-\mathrm{N}$ angles ranged from $85^{\circ}$ to $91^{\circ}$ in the trinuclear complexes, the angles between calculated pyridyl planes ranged from $62^{\circ}$ to $73^{\circ}$, consistent with some form of packing perturbation (Table 3 ). The attractive aromatic interactions observed between the complex ions of 1 and 2 solvomorphs include concerted orthogonal fourfold aryl embraces $(\mathrm{EF})_{4}$ (Figure 13) as well as isolated EF, outer OFF, and inner OFF interactions (Table 3). ${ }^{41}$ Toluene provided an additional synthon for aromatic interactions in 2d-2g (Table 3 and Figure 14). All meso and pseudo-meso complexes had extensive $\mathrm{P}_{2}$-(EF) interactions between end-toend aligned molecules. Only the racemic complexes $2 \mathrm{~d}$ and $2 \mathrm{e}$ and the meso complex with the most puckered core $2 \mathrm{f}$ were found to have $\mathrm{P}_{2}$-(OFF) interactions. With the exception of $\mathbf{2 e}$, the complex ions were packed in end-to-end columns.

2.2.3. Side-To-Side Stacking Arrangements. The symmetric and pseudosymmetric rod-shaped complex ions exhibited a variety of side-to-side stacking arrangements (Table 3). Two- 
Table 2. Hydrogen Bond Metrics for New Trinuclear Complexes [Å and deg]

\begin{tabular}{|c|c|c|c|c|c|}
\hline interaction & $d(\mathrm{D}-\mathrm{H})(\AA)$ & $d(\mathrm{H} \cdots \mathrm{A})(\AA)$ & $d(\mathrm{D} \cdots \mathrm{A})(\AA)$ & $\angle$ (DHA) $(\operatorname{deg})$ & symmetry \\
\hline \multicolumn{6}{|c|}{$\overline{\left[\mathrm{Zn}(\mathrm{ZnL})_{2}\right]\left(\mathrm{ClO}_{4}\right)_{2} \cdot 2 \mathrm{CH}_{3} \mathrm{CN}(1 \mathrm{c})}$} \\
\hline $\mathrm{N}(2)-\mathrm{H}(2) \cdots \mathrm{O}(1)$ & 1.00 & 2.08 & $3.018(3)$ & 155.4 & $x+1 / 2,-y+1 / 2, z$ \\
\hline $\mathrm{N}(4)-\mathrm{H}(4) \cdots \mathrm{O}(6)$ & 1.00 & 2.08 & $3.035(3)$ & 158.1 & $x, y, z$ \\
\hline $\mathrm{N}(6)-\mathrm{H}(6) \cdots \mathrm{N}(10)$ & 1.00 & 2.13 & $3.053(4)$ & 153.3 & $x+1 / 2,-y+3 / 2, z$ \\
\hline $\mathrm{N}(8)-\mathrm{H}(8) \cdots \mathrm{O}(5)$ & 1.00 & 2.08 & $3.005(3)$ & 153.2 & $-x+1,-y+1, z+1 / 2$ \\
\hline \multicolumn{6}{|c|}{$\left[\mathrm{Hg}(\mathrm{ZnL})_{2}\right]\left(\mathrm{ClO}_{4}\right)_{2} 2 \mathrm{H}_{2} \mathrm{O}(2 \mathrm{a})$} \\
\hline $\mathrm{N}(2)-\mathrm{H}(2) \cdots \mathrm{O}(1 \mathrm{~A})$ & 1.00 & 2.52 & $3.190(17)$ & 124.1 & $y,-x,-z+1$ \\
\hline $\mathrm{N}(2)-\mathrm{H}(2) \cdots \mathrm{O}(3 \mathrm{~B})$ & 1.00 & 2.36 & $3.25(2)$ & 147.4 & $y,-x,-z+1$ \\
\hline $\mathrm{N}(4)-\mathrm{H}(4) \cdots \mathrm{O}(5)$ & 1.00 & 1.92 & $2.858(14)$ & 155.7 & $y,-x+1,-z+1$ \\
\hline $\mathrm{O}(5)-\mathrm{H}(1 \mathrm{~W}) \cdots \mathrm{S}(1)$ & $0.83(3)$ & $2.45(9)$ & $3.221(11)$ & $155(18)$ & $-x+1,-y, z$ \\
\hline $\mathrm{O}(5)-\mathrm{H}(2 \mathrm{~W}) \cdots \mathrm{O}(2 \mathrm{~A})$ & $0.83(3)$ & $2.09(5)$ & $2.90(3)$ & $165(15)$ & $x, y, z$ \\
\hline $\mathrm{O}(5)-\mathrm{H}(2 \mathrm{~W}) \cdots \mathrm{O}(2 \mathrm{~B})$ & $0.83(3)$ & $2.01(10)$ & $2.76(2)$ & $149(17)$ & $x, y, z$ \\
\hline \multicolumn{6}{|c|}{$\left[\mathrm{Hg}(\mathrm{ZnL})_{2}\right]\left(\mathrm{ClO}_{4}\right)_{2} \cdot 3 \mathrm{CH}_{3} \mathrm{CN} \cdot 0.75$ Toluene $(2 \mathrm{~d})$} \\
\hline $\mathrm{N}(2)-\mathrm{H}(2) \cdots \mathrm{O}(1 \mathrm{~B})$ & 1.00 & 2.21 & $3.056(8)$ & 140.9 & $x,-y+1, z+1 / 2$ \\
\hline $\mathrm{N}(4)-\mathrm{H}(4) \cdots \mathrm{O}(5)$ & 1.00 & 2.35 & $3.174(4)$ & 138.9 & $-x+1 / 2,-y+1 / 2,-z+1$ \\
\hline $\mathrm{N}(4)-\mathrm{H}(4) \cdots \mathrm{O}(6)$ & 1.00 & 2.38 & $3.232(6)$ & 143.2 & $-x+1 / 2,-y+1 / 2,-z+1$ \\
\hline $\mathrm{N}(6)-\mathrm{H}(6 \mathrm{~N}) \cdots \mathrm{O}(2 \mathrm{~B})$ & 1.00 & 2.10 & $3.024(4)$ & 152.3 & $-x+1,-y+1,-z+1$ \\
\hline $\mathrm{N}(8)-\mathrm{H}(8) \cdots \mathrm{O}(7)$ & 1.00 & 2.10 & $3.051(4)$ & 158.2 & $x, y, z$ \\
\hline \multicolumn{6}{|c|}{$\left[\mathrm{Hg}(\mathrm{ZnL})_{2}\right]\left(\mathrm{ClO}_{4}\right)_{2} \cdot \mathrm{CH}_{3} \mathrm{CN} \cdot 1.5$ Toluene $(2 \mathrm{e})$} \\
\hline $\mathrm{N}(2)-\mathrm{H}(2 \mathrm{~N}) \cdots \mathrm{O}(6 \mathrm{~A})$ & 1.00 & 2.66 & $3.516(11)$ & 143.6 & $x+1, y, z$ \\
\hline $\mathrm{N}(2)-\mathrm{H}(2 \mathrm{~N}) \cdots \mathrm{O}(6 \mathrm{~B})$ & 1.00 & 2.20 & $3.132(17)$ & 153.5 & $x+1, y, z$ \\
\hline $\mathrm{N}(2)-\mathrm{H}(2 \mathrm{~N}) \cdots \mathrm{O}(8 \mathrm{~A})$ & 1.00 & 2.07 & $2.980(9)$ & 149.6 & $x+1, y, z$ \\
\hline $\mathrm{N}(4)-\mathrm{H}(4 \mathrm{~N}) \cdots \mathrm{O}(7 \mathrm{~A})$ & 1.00 & 2.03 & $3.024(10)$ & 173.6 & $x, y, z$ \\
\hline $\mathrm{N}(4)-\mathrm{H}(4 \mathrm{~N}) \cdots \mathrm{O}(7 \mathrm{~B})$ & 1.00 & 2.01 & $2.949(14)$ & 156.1 & $x, y, z$ \\
\hline $\mathrm{N}(6)-\mathrm{H}(6 \mathrm{~N}) \cdots \mathrm{O}(3)$ & 1.00 & 2.08 & $3.071(7)$ & 173.6 & $-x+2,-y+1,-z+1$ \\
\hline $\mathrm{N}(8)-\mathrm{H}(8 \mathrm{~N}) \cdots \mathrm{O}(1)$ & 1.00 & 2.18 & $3.072(7)$ & 147.9 & $-x+1,-y+1,-z+1$ \\
\hline $\mathrm{N}(8)-\mathrm{H}(8 \mathrm{~N}) \cdots \mathrm{O}(4)$ & 1.00 & 2.57 & $3.417(13)$ & 142.3 & $-x+1,-y+1,-z+1$ \\
\hline \multicolumn{6}{|c|}{$\left[\mathrm{Hg}(\mathrm{ZnL})_{2}\right]\left(\mathrm{ClO}_{4}\right)_{2} \cdot \mathrm{CH}_{3} \mathrm{CN} \cdot 0.5$ Toluene $(2 \mathrm{f})$} \\
\hline $\mathrm{N}(2)-\mathrm{H}(2) \cdots \mathrm{O}(1)$ & 1.00 & 2.23 & $3.061(6)$ & 139.3 & $x, y, z$ \\
\hline $\mathrm{N}(2)-\mathrm{H}(2) \cdots \mathrm{O}(2)$ & 1.00 & 2.35 & $3.182(6)$ & 139.9 & $x, y, z$ \\
\hline $\mathrm{N}(4)-\mathrm{H}(4) \cdots \mathrm{O}(6)$ & 1.00 & 2.38 & $3.127(9)$ & 130.6 & $x, y+1, z$ \\
\hline $\mathrm{N}(6)-\mathrm{H}(6) \cdots \mathrm{N}(9)$ & 1.00 & 2.14 & $3.085(7)$ & 157.5 & $x+1, y, z$ \\
\hline $\mathrm{N}(8)-\mathrm{H}(8) \cdots \mathrm{O}(5)$ & 1.00 & 2.24 & $3.216(7)$ & 164.7 & $x, y, z$ \\
\hline \multicolumn{6}{|c|}{$\left[\mathrm{Hg}(\mathrm{ZnL})_{2}\right]\left(\mathrm{ClO}_{4}\right)_{2} \cdot$ Toluene $(2 \mathrm{~g})$} \\
\hline $\mathrm{N}(2)-\mathrm{H}(2 \mathrm{~N}) \cdots \mathrm{O}(3)$ & 1.00 & 1.97 & $2.925(7)$ & 158.7 & $x, y, z$ \\
\hline $\mathrm{N}(4)-\mathrm{H}(4 \mathrm{~N}) \cdots \mathrm{O}(4)$ & 1.00 & 2.65 & $3.608(10)$ & 159.5 & $-x+1,-y+1,-z+1$ \\
\hline
\end{tabular}

dimensional lamellar packing arrangements were observed for individual stereoisomers in orthorhombic $1 \mathrm{c}$ and for independent molecules in tetragonal $\mathbf{1}^{\prime} \mathbf{a}$ and $\mathbf{2 a}$. Columnar packing arrangements were found for monoclinic complexes $\mathbf{2 d}$ and $2 \mathrm{~g}$. By contrast, the triclinic complexes $\mathbf{1 b}, \mathbf{2 e}$, and $2 \mathrm{f}$ had lamellar stacking of inversion-related pairs. Side-to-side arrangements produced sizable solvent-filled channels parallel to the (010) crystal plane and along the $a$ axis in $\mathbf{2 d}$ and $\mathbf{2 e}$, respectively (Figure 15), consistent with the observed instability of their crystals to removal of the mother liquor. Solvent molecules were confined to small enclosed pockets in the remaining solvomorphs.

2.3. Variable Temperature Proton NMR. Previous NMR studies of $\mathbf{1}^{\prime} \mathbf{a}$ and $\mathbf{1 b}$ conducted in highly polar dimethylsulfoxide- $d_{6}$ only permitted confirmation of constituents because information obtainable from multiplet patterns was obscured by broadening. ${ }^{32,33}$ By contrast, the ${ }^{1} \mathrm{H}$ NMR of $1 \mathrm{c}$ in dry $\mathrm{CD}_{3} \mathrm{CN}$ at $20{ }^{\circ} \mathrm{C}$ revealed 1 predominant ligand environment with 10 distinguishable resonances for the 10 nonexchangeable protons of $\mathbf{L}$ (Figure 16b). Although comparisons between the solutionstate spectra and solid-state structures must always be made carefully, the methylene and ethylene protons exhibited a strong geminal coupling, which requires the formation of two chelate rings and a slow intermolecular ligand exchange on the ${ }^{1} \mathrm{H}-{ }^{1} \mathrm{H}$ coupling constant time scale. Furthermore, 8 of the 10 resonances for nonexchangeable protons were shifted downfield, which is a common result of the deshielding influence of $\sigma$ donation to a metal cation. Resonances found upfield with respect to the free ligand were associated with $\mathrm{H}_{\mathrm{a}}$ and one of the $\mathrm{H}_{\mathrm{h}}$ protons. The solid-state structures of $\mathbf{1}^{\prime} \mathbf{a}, \mathbf{1} \mathbf{b}$, and $\mathbf{1 c}$ suggest that these protons would encounter the shielding influence of ring current in the $\left[\mathrm{Zn}(\mathrm{ZnL})_{2}\right]^{2+}$ complex cation (Figure S5). ${ }^{42}$ Therefore, the solution ${ }^{1} \mathrm{H}$ NMR spectrum is fully consistent with the assignment of the prevalent solution species to $\left[\mathrm{Zn}(\mathrm{ZnL})_{2}\right]^{2+}$.

The proton NMR of both precipitated $\mathbf{1}$ and recrystallized 1c in dry $\mathrm{CD}_{3} \mathrm{CN}$ at $20{ }^{\circ} \mathrm{C}$ consistently had a series of small additional resonances with poorly resolved splitting. The intensities of these minor spectral features were diminished by cooling to $-40{ }^{\circ} \mathrm{C}$ (Figure 16c), suggesting that the predominant species was subject to limited thermal fragmentation in solution. Furthermore, the minor resonances collapsed into major resonances, and geminal splitting was lost reversibly upon heating to $60{ }^{\circ} \mathrm{C}$, indicating that either intermolecular exchange or intramolecular reorganization processes were rapid at an elevated temperature (Figure 16a). 
a)
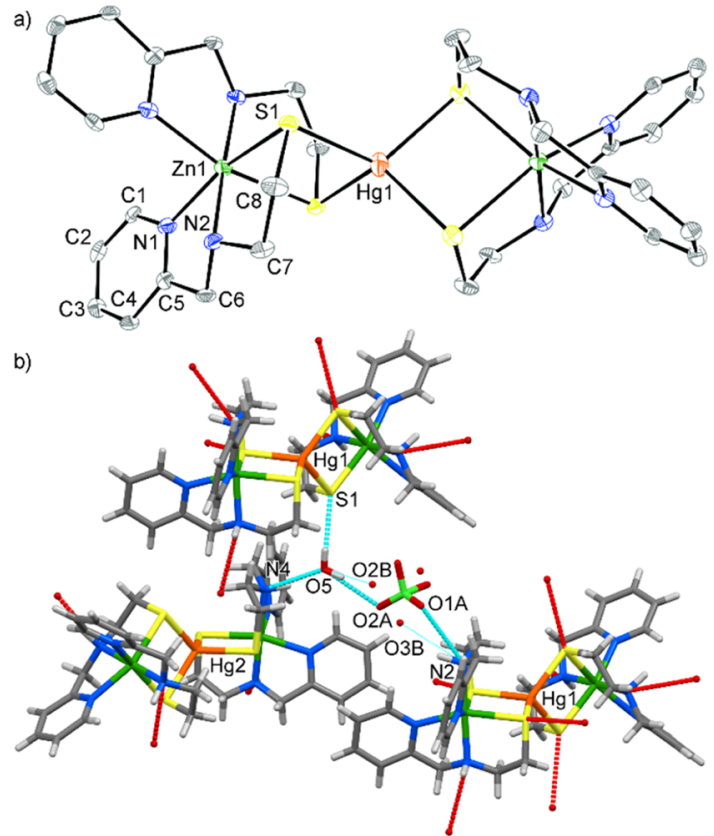

Figure 6. (a) Thermal ellipsoid drawing for one of two similar complex ions in 2a showing the crystallographic numbering scheme. Thermal ellipsoids are shown at 50\% probability. (b) Hydrogenbonding network diagram. Hydrogen bonds are indicated by dashed cyan lines.

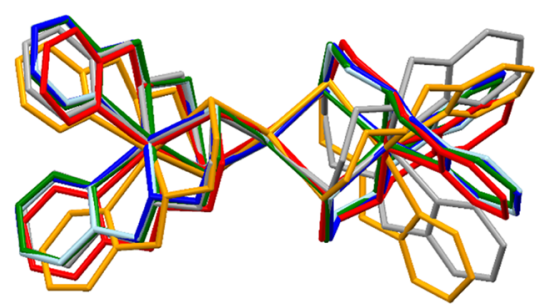

Figure 7. Molecular overlay of all $\left[\mathrm{Hg}\left(\mathrm{ZnL}_{2}\right)_{2}\right]^{2+}$ complex ions from the asymmetric units of different solid forms of 2 . 2a, blue and light blue; $2 \mathrm{~d}$, grey; $2 \mathrm{e}$, orange; $\mathbf{2 f}$, red; and $\mathbf{2 g}$, dark green.

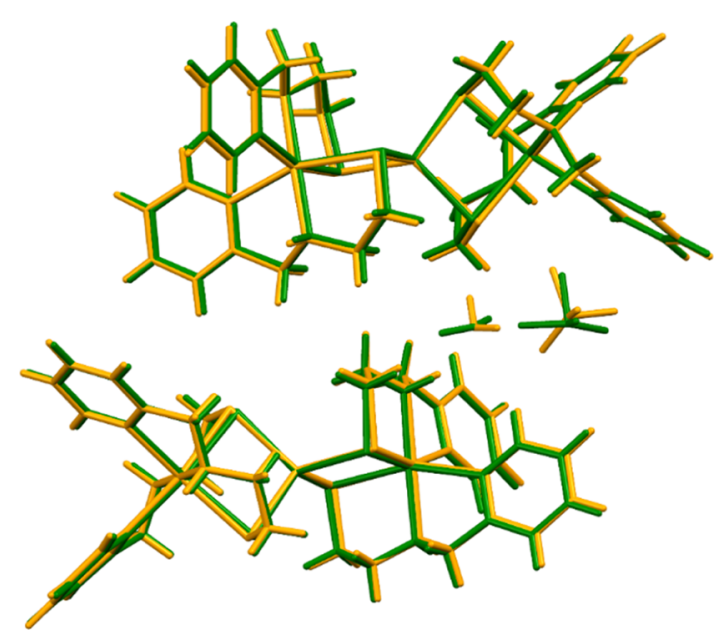

Figure 8. Metal ion overlay of $\mathbf{1}^{\prime} \mathbf{a}$ (green) and $\mathbf{2 a}$ (yellow orange).

In $\mathrm{CD}_{3} \mathrm{CN}$ solution, the various solvates of $\mathbf{2}$ isolated in bulk had identical chemical shifts for the protons of $\mathbf{L}$. Ligand proton chemical shifts for 2 were within $\pm 0.02 \mathrm{ppm}$ of those observed for 1 with the exception of the $\mathrm{H}_{\mathrm{h}}$ protons, which
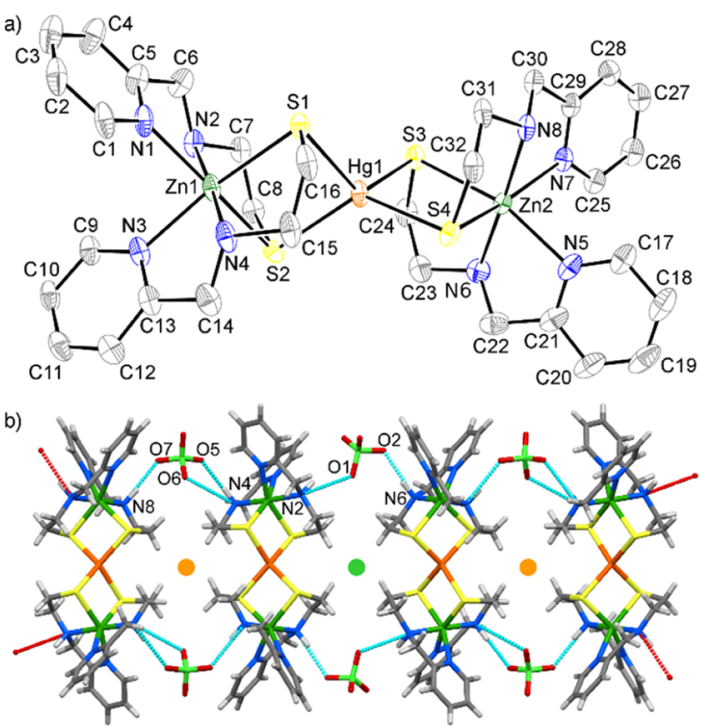

Figure 9. (a) Thermal ellipsoid drawing for the complex ion of $\mathbf{2 d}$ showing the crystallographic numbering scheme. Thermal ellipsoids are shown at $50 \%$ probability. (b) Hydrogen-bonding ribbon diagram viewed along $b$ (solvents omitted). Hydrogen bonds are indicated by dashed cyan lines. Circles indicate a crystallographic $C_{2}$ axis (lime green) and inversion centers (orange).
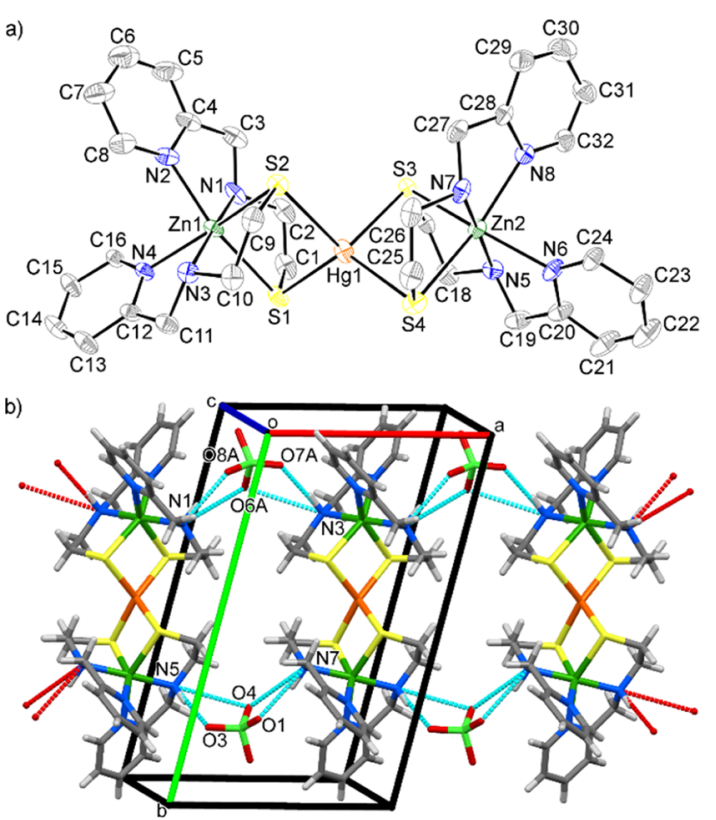

Figure 10. (a) Thermal ellipsoid drawing for the complex ion of $2 \mathbf{e}$ showing a partial crystallographic numbering scheme. Thermal ellipsoids are shown at $50 \%$ probability. (b) Hydrogen-bonding ribbon diagram (solvents omitted). Hydrogen bonds are indicated by dashed cyan lines. Only the position of highest occupancy is shown for the disordered perchlorate.

were somewhat more deshielded with respect to the free ligand (Figure 17). Significantly, the $\mathrm{H}_{\mathrm{h}}$ protons would be expected to be impacted the most by switching out the central metal ion of the $\left[\mathrm{Zn}(\mathrm{ZnL})_{2}\right]^{2+}$ complex cation for $\mathrm{Hg}(\mathrm{II})$. At $20{ }^{\circ} \mathrm{C}$, the methylene protons of $\mathbf{2}$ were geminally split by each other and vicinally split by the proton attached to nitrogen, as observed for 1 . Aromatic ligand protons $\mathrm{H}_{\mathrm{b}}, \mathrm{H}_{\mathcal{c}}$ and $\mathrm{H}_{\mathrm{d}}$ each had a single resonance with characteristic multiplicity. However, two partially resolved doublets for $\mathrm{H}_{\mathrm{a}}$ with $\Delta \delta 0.026 \mathrm{ppm}$ in an 

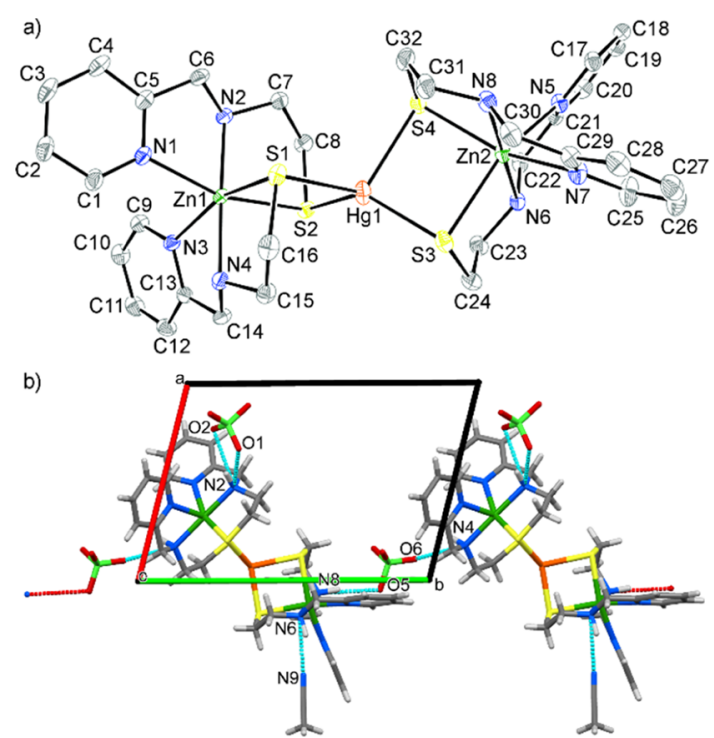

Figure 11. (a) Thermal ellipsoid drawing for the complex ion of $\mathbf{2} \mathbf{f}$ showing the crystallographic numbering scheme. Thermal ellipsoids are shown at $50 \%$ probability. (b) Hydrogen-bonding ribbon diagram (nonparticipating solvents omitted). Hydrogen bonds are indicated by dashed cyan lines.
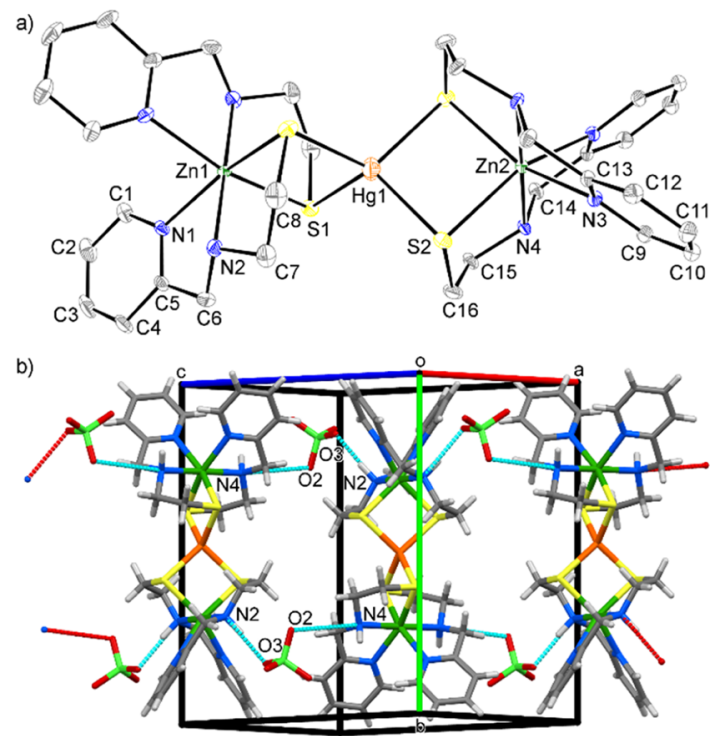

Figure 12. (a) Thermal ellipsoid drawing for the complex ion of $\mathbf{2 g}$ showing the crystallographic numbering scheme. Thermal ellipsoids are shown at $50 \%$ probability. (b) Hydrogen-bonding ribbon diagram (solvent omitted). Hydrogen bonds are indicated by dashed cyan lines.

approximate 1:3 ratio were observed (Figure S6), indicating that there was more than one ligand environment in a slow exchange on the chemical shift time scale. The meso $(\Delta \Lambda)$ and diastereotopic $(\Delta \Delta / \Lambda \Lambda)$ forms of 2 , characterized crystallographically (vide supra), provide a satisfactory explanation for the observed spectra. Because the $\mathrm{H}_{\mathrm{a}}$ protons of related multidentate pyridyl ligands have typically demonstrated much greater sensitivity to subtle differences in the environment when bound to group 12 metal ions, coincidental stereoisomer chemical shifts for the remaining protons are reasonable (Figure 17c). ${ }^{30,43-45}$ Significantly, at $-40{ }^{\circ} \mathrm{C}$, the two chemical shift environments for $\mathrm{H}_{\mathrm{a}}$ were better resolved, and a second chemical shift environment was partially resolved for $\mathrm{H}_{h}$ with
Table 3. Aromatic-Stacking Interactions Involving Pyridyl (P) and Toluene (T) Rings Observed in the Solvomorphs of 1 and 2

\begin{tabular}{|c|c|c|c|c|c|}
\hline & & aromatic & teractions & & \\
\hline & 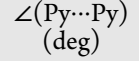 & end-to-end & other & $\begin{array}{l}\text { side-to-side } \\
\text { packing motif }\end{array}$ & refs \\
\hline $1^{\prime} \mathbf{a}$ & $70.11,68.9$ & $\mathrm{P}_{4^{-}}(\mathrm{EF})_{4}$ & & 2D lamellar & 32 \\
\hline $1 b$ & $62.2,67.08$ & $\mathrm{P}_{4^{-}}(\mathrm{EF})_{4}$ & & lamellar & 33 \\
\hline $1 c$ & $71.0,71.5$ & $\mathrm{P}_{4^{-}}(\mathrm{EF})_{4}$ & & 2D lamellar & $\begin{array}{l}\text { this } \\
\text { work }\end{array}$ \\
\hline $2 a$ & $70.4,70.9$ & $\mathrm{P}_{4^{-}}(\mathrm{EF})_{4}$ & & 2D lamellar & $\begin{array}{l}\text { this } \\
\text { work }\end{array}$ \\
\hline $2 d$ & $64.4,70.0$ & $\begin{array}{l}\text { outer } \\
\mathrm{P}_{2^{-}}(\mathrm{OFF}) \\
\mathrm{P}_{2^{-}}(\mathrm{EF})\end{array}$ & PT-(EF) & columnar & $\begin{array}{l}\text { this } \\
\text { work }\end{array}$ \\
\hline $2 e$ & $71.5,72.8$ & $\begin{array}{l}\text { inner } \\
\mathrm{P}_{2^{-}}(\mathrm{OFF}) \\
\mathrm{P}_{2^{-}}(\mathrm{EF})\end{array}$ & PT-(EF) & lamellar & $\begin{array}{l}\text { this } \\
\text { work }\end{array}$ \\
\hline $2 \mathrm{f}$ & $69.0,73.13$ & $\begin{array}{l}\mathrm{P}_{2^{-}}(\mathrm{EF}) \\
\text { outer } \\
\mathrm{P}_{2^{-}}(\mathrm{OFF})\end{array}$ & PT-(OFF) & lamellar & $\begin{array}{l}\text { this } \\
\text { work }\end{array}$ \\
\hline $2 \mathrm{~g}$ & $62.4,64.9$ & $\mathrm{P}_{4^{-}}(\mathrm{EF})_{4}$ & PT-(EF) & columnar & $\begin{array}{l}\text { this } \\
\text { work }\end{array}$ \\
\hline
\end{tabular}

roughly one-third the intensity of the main $\mathrm{H}_{h}$ resonance (Figure S7). At an elevated temperature, the resonances for $\mathrm{H}_{\mathrm{a}}$ and all aliphatic protons collapsed to broad singlets, consistent with a thermally-induced bond cleavage process permitting interconversion of the stereoisomers.

2.4. ESI-MS. Additional support for assigning the major species observed by solution ${ }^{1} \mathrm{H}$ NMR to $\mathbf{1}$ and $\mathbf{2}$ was obtained by ESI-MS. The very sensitive soft ionization technique ESIMS is well-suited for the characterization of a mixture of complex ions with different metal-to-ligand ratios. However, the percentage dissociation is expected to be somewhat higher in ESI-MS studies, which require significantly lower solution concentrations than ${ }^{1} \mathrm{H}$ NMR studies. Because of potential differences in the gas phase-transfer efficiency and detection response factors as well as dynamic range limitations, our use of ESI-MS has been primarily qualitative.

2.4.1. ESI-MS Characterization of 1. Solvates of tri-zinc complex 1 were first prepared before the widespread availability of ESI-MS. ${ }^{32,33}$ A dilute acetonitrile solution of $1 \mathrm{c}$ gave rise to a positive ion ESI-MS spectrum with five main components (Figure 18a). Under optimized conditions, a set of peaks with the highest intensity at $m / z$ 432, well-matched with the predicted isotope pattern for $\left[\mathrm{Zn}_{3} \mathbf{L}_{4}\right]^{2+}$, was the base peak (Figure $18 \mathrm{~b}$ ), and a set of isotope peaks around $\mathrm{m} / \mathrm{z} 963$ matching the theoretical isotope pattern for $\left[\mathrm{Zn}_{3} \mathrm{~L}_{4} \mathrm{ClO}_{4}\right]^{+}$was also found (Figure 18c). The isolated trinuclear cations underwent chemically induced dissociation processes 1 and 2 (Figure S8).

$$
\begin{aligned}
& {\left[\mathrm{Zn}_{3} \mathbf{L}_{4}\right]^{2+} \rightarrow[\mathrm{ZnL}]^{+}+\left[\mathrm{Zn}_{2} \mathbf{L}_{3}\right]^{+}} \\
& {\left[\mathrm{Zn}_{3} \mathbf{L}_{4} \mathrm{ClO}_{4}\right]^{+} \rightarrow\left[\mathrm{ZnLClO}_{4}\right]+\left[\mathrm{Zn}_{2} \mathbf{L}_{3}\right]^{+}}
\end{aligned}
$$

Significantly, the relative abundance of the peaks assigned to mononuclear complexes increased in intensity, whereas peaks assigned to bi- and trinuclear complexes decreased, with either decreased concentration or increased capillary voltage as would be expected (data not shown).

2.4.2. ESI-MS Characterization of 2. A dilute acetonitrile solution of 2 gave rise to a positive ion ESI-MS spectrum with 


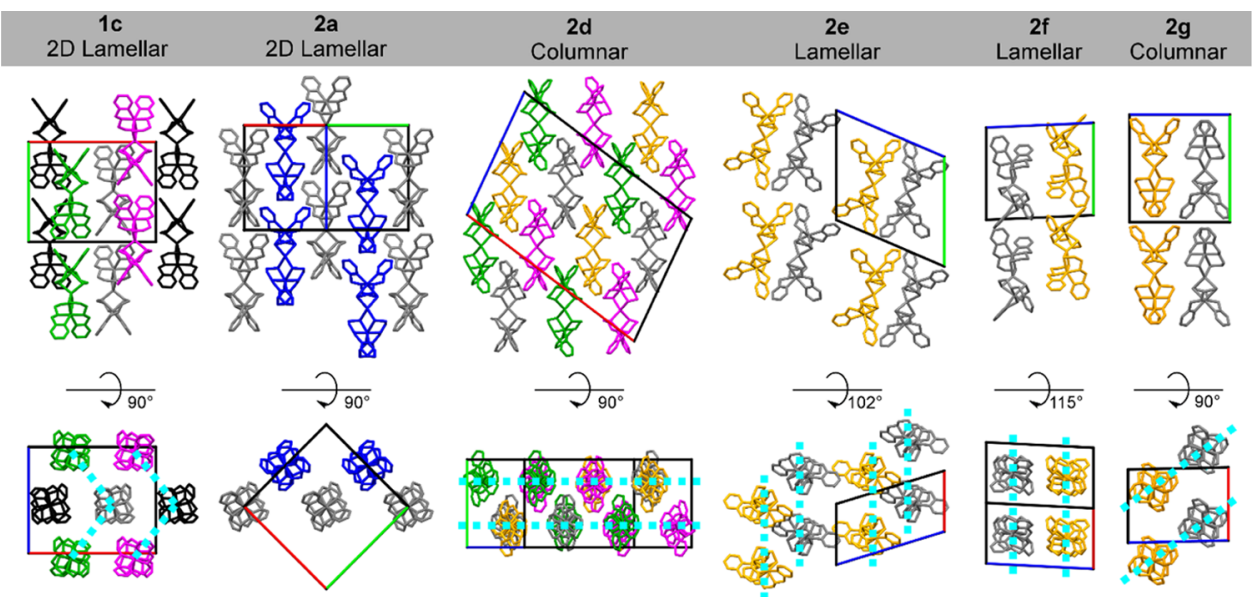

Figure 13. Packing diagrams highlighting end-to-end and side-to-side orientations of symmetry-related (1c, $2 \mathrm{~d}, \mathbf{2 e}, \mathbf{2 f}$, and $\mathbf{2 g})$ or independent $(\mathbf{2 a})$ molecules. Solvents and perchlorates are omitted for clarity. Directionality of hydrogen-bonding ribbons is indicated by dashed cyan lines.

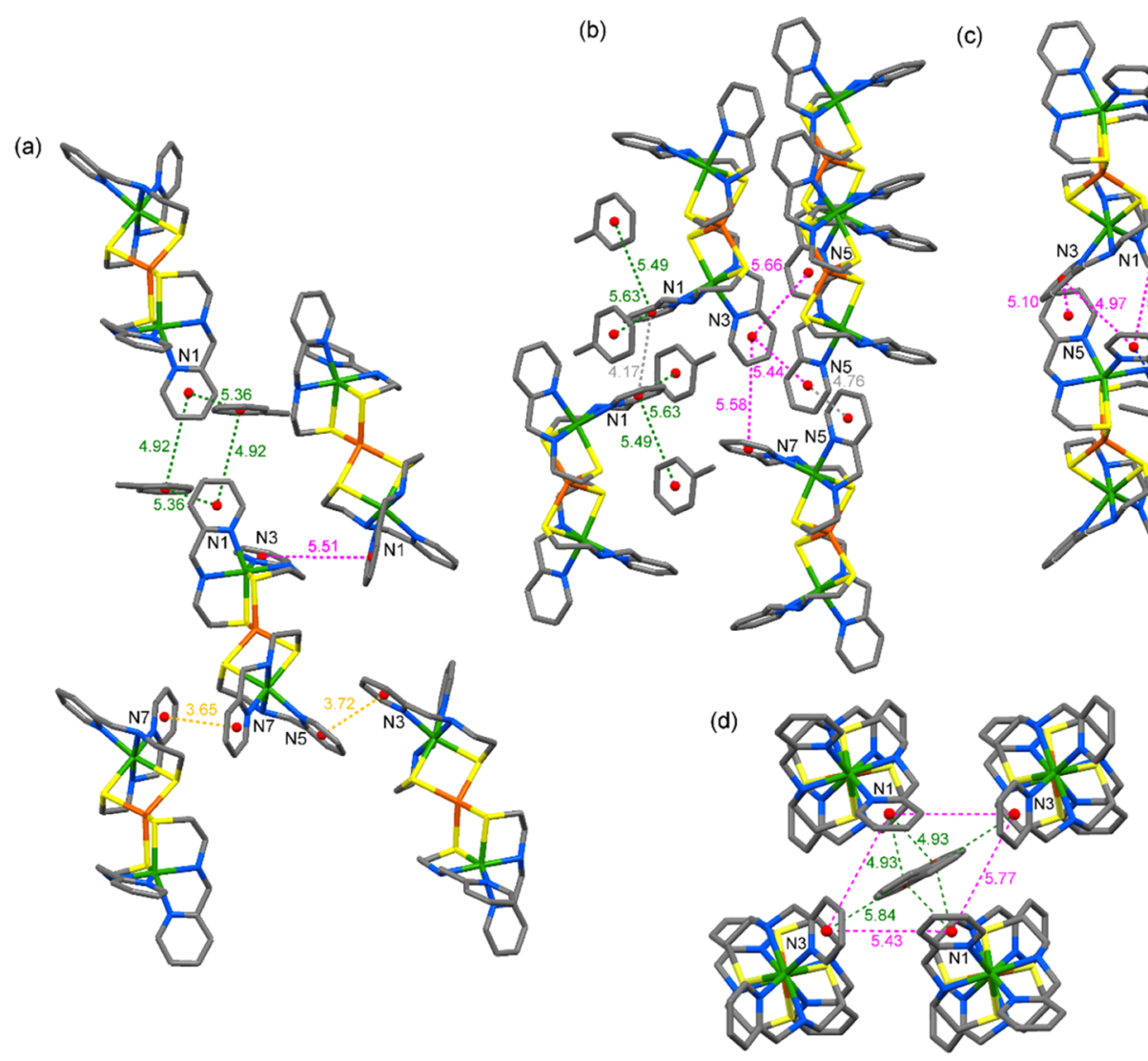

Figure 14. Aromatic-stacking interactions of toluene (T) and pyridyl (P) rings identified by their nitrogen atoms in (a) 2d, (b) 2e, (c) 2f, and (d) 2g. Hydrogens, perchlorates, and nonparticipating or low occupancy solvents are omitted for clarity. Centroid-to-centroid distances for offset face-toface $\pi-\pi$ interactions (OFF) and edge-to-face $\sigma-\pi$ interactions (EF) are color coded by type: amber, outer $\mathrm{P}_{2}-(\mathrm{OFF})$; gray, inner $\mathrm{P}_{2}-(\mathrm{OFF})$; blue, outer PT-(OFF); magenta, $\mathrm{P}_{2}-(\mathrm{EF})$; and green, $\mathrm{PT}-(\mathrm{EF})$.

six main components (Figure 19). Under optimized conditions, the base set of isotope peaks at $\mathrm{m} / z 500$ matched the isotope pattern predicted for the divalent mixed metal ion $\left[\mathrm{HgZn}_{2} \mathbf{L}_{4}\right]^{2+}$, and negligible amounts of its homometallic counterparts were detected. Similarly, a set of isotope peaks with significant abundance around $\mathrm{m} / z 1099$ was well-matched with predictions for $\left[\mathrm{HgZn}_{2} \mathrm{~L}_{4} \mathrm{ClO}_{4}\right]^{+} ;\left[\mathrm{Zn}_{3} \mathbf{L}_{4} \mathrm{ClO}_{4}\right]^{+}$had an insignificant intensity. The ESI-MS spectrum for 2 had peaks for $[\mathrm{ZnL}]^{+},\left[\mathrm{ZnLC}_{2} \mathrm{H}_{3} \mathrm{~N}\right]^{+}$, and $\left[\mathrm{Zn}_{2} \mathrm{~L}_{3}\right]^{+}$in common with the spectrum for 1 as well as an isotope cluster around $m / z 767$ assigned to $\left[\mathrm{HgZnL}_{3}\right]^{+}$based on a matching isotope pattern. The isolated divalent and monovalent trinuclear cations of 2 underwent chemically induced dissociation processes 3 and 4 (Figure S9), respectively. A detailed investigation of gas-phase fragmentation pathways to explain why different bimetallic fragments were formed from these related ions is beyond the scope of this work.

$$
\left[\mathrm{HgZn}_{2} \mathbf{L}_{4}\right]^{2+} \rightarrow[\mathrm{HgL}]^{+}+\left[\mathrm{Zn}_{2} \mathbf{L}_{3}\right]^{+}
$$




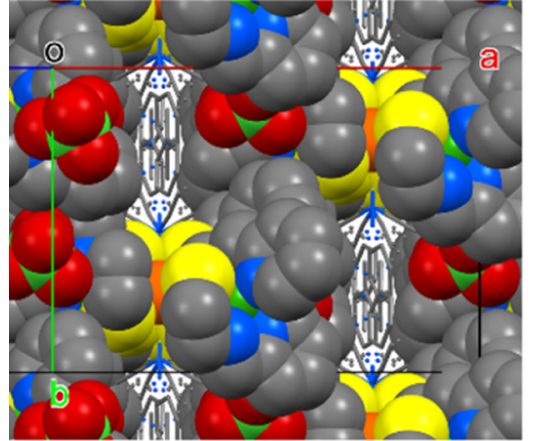

(a)

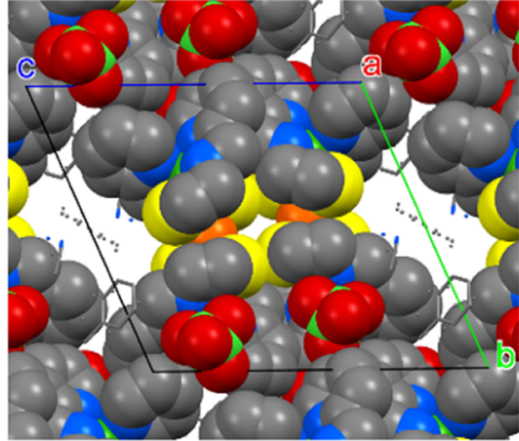

(b)

Figure 15. Solvent channels observed in (a) $2 \mathrm{~d}$ viewed along the (010) plane and (b) $2 \mathrm{e}$ viewed along the $a$ axis. Complex ions and perchlorates are shown in space-fill. Acetonitrile and toluene solvent molecules are shown in the channels. Hydrogens are omitted for clarity.

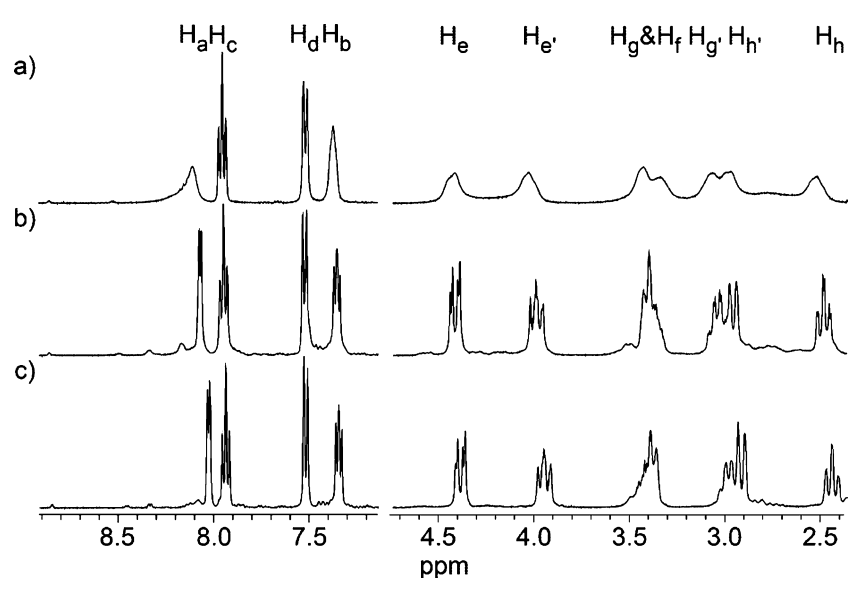

Figure 16. Variable temperature ${ }^{1} \mathrm{H} \mathrm{NMR}$ of $1 \mathrm{c}$ in $\mathrm{CD}_{3} \mathrm{CN}$ at (a) 60 , (b) 20 , and (c) $-40{ }^{\circ} \mathrm{C}$.

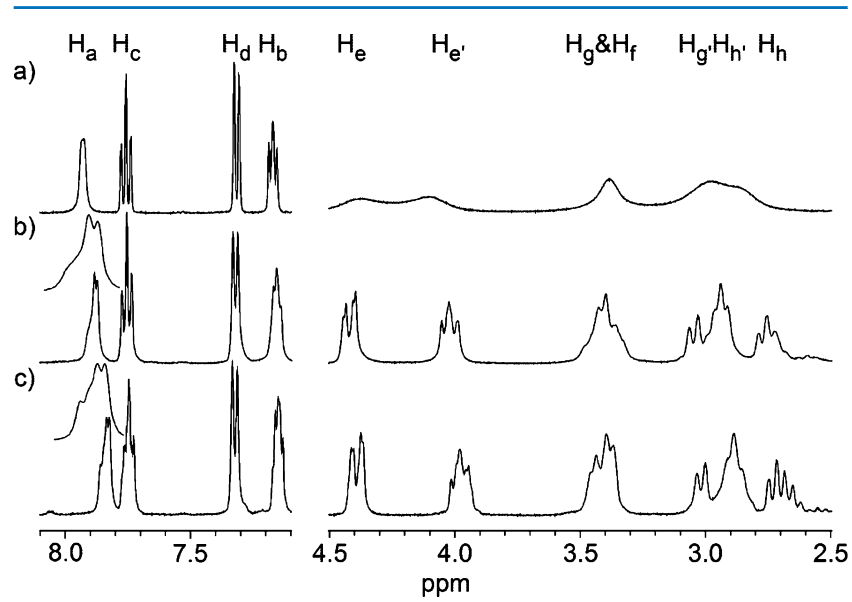

Figure 17. Variable temperature ${ }^{1} \mathrm{H}$ NMR of $2 \mathrm{~d}$ in $\mathrm{CD}_{3} \mathrm{CN}$ at (a) 60 , (b) 20 , and (c) $-40{ }^{\circ} \mathrm{C}$. The insets highlight the two environments observed for $\mathrm{H}_{\mathrm{a}}$.

$$
\left[\mathrm{HgZn}_{2} \mathbf{L}_{4} \mathrm{ClO}_{4}\right]^{+} \rightarrow\left[\mathrm{ZnLClO}_{4}\right]+\left[\mathrm{HgZnL}_{3}\right]^{+}
$$

2.4.3. ESI-MS Investigation of Metal and Ligand Redistribution. One of the defining properties of metallothionein is variable metal occupancy. Our previous ESI-MS studies of $\left[\mathrm{Hg}_{5} \mathrm{~L}_{6}\right]\left(\mathrm{ClO}_{4}\right)_{4}$ (4) revealed elaborate speciation involving $\left[\mathrm{Hg}_{n} \mathbf{L}_{n+1}\left(\mathrm{ClO}_{4}\right)_{n-2}\right]^{+},\left[\mathrm{Hg}_{n} \mathbf{L}_{n}\left(\mathrm{ClO}_{4}\right)_{n-1}\right]^{+}$, and $\left[\mathrm{Hg}_{n} \mathrm{~L}_{n-1}\left(\mathrm{ClO}_{4}\right)_{n}\right]^{+}$ion families. ${ }^{30}$ Initial efforts to exchange the central $\mathrm{Zn}$ (II) of 1 for $\mathrm{Hg}$ (II) used $\mathrm{Hg}\left(\mathrm{ClO}_{4}\right)_{2}$.

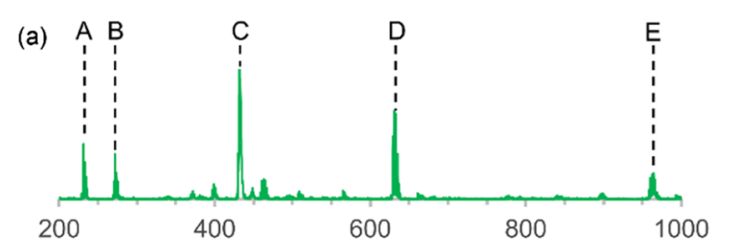

(b)

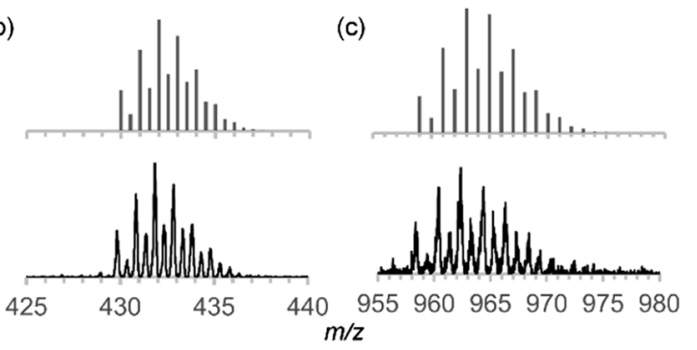

Figure 18. (a) ESI-MS of a nominally $0.1 \mathrm{mM}$ acetonitrile solution of 1. Labeled peak assignments with $\mathrm{X}=\mathrm{ClO}_{4}{ }^{-}$(highest intensity $\mathrm{m} / z$ ): $\mathrm{A}[\mathrm{ZnL}]^{+}(231) ; \mathrm{B}\left[\mathrm{ZnLCH}_{3} \mathrm{CN}\right]^{+}(272) ; \mathrm{C}\left[\mathrm{Zn}_{3} \mathbf{L}_{4}\right]^{2+}(432) ; \mathrm{D}$ $\left[\mathrm{Zn}_{2} \mathbf{L}_{3}\right]^{+}$(633); and $\mathrm{E}\left[\mathrm{Zn}_{3} \mathbf{L}_{4} \mathrm{X}\right]^{+}$(963). Calculated (top) and observed (bottom) isotope pattern for (b) $\left[\mathrm{Zn}_{3} \mathrm{~L}_{4}\right]^{2+}$ and (c) $\left[\mathrm{Zn}_{3} \mathrm{~L}_{4} \mathrm{ClO}_{4}\right]^{+}$.

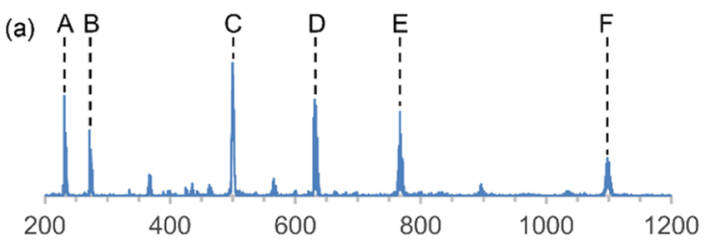

(b)

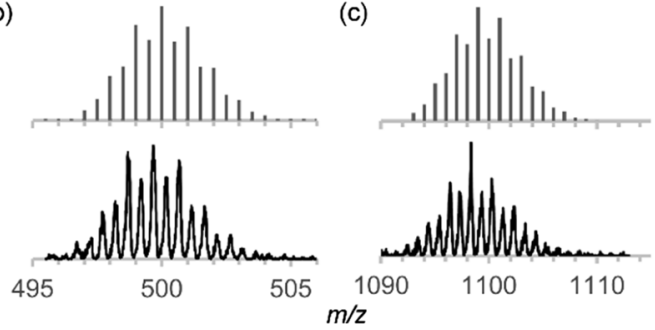

Figure 19. (a) ESI-MS of a nominally $0.1 \mathrm{mM}$ acetonitrile solution of 2. Labeled peak assignments with $\mathrm{X}=\mathrm{ClO}_{4}{ }^{-}$(highest intensity $\mathrm{m} / z$ ): $\mathrm{A}[\mathrm{ZnL}]^{+}(231) ; \mathrm{B}\left[\mathrm{ZnLC}_{2} \mathrm{H}_{3} \mathrm{~N}\right]^{+}(272) ; \mathrm{C}\left[\mathrm{HgZn}_{2} \mathrm{~L}_{4}\right]^{2+}(500) ; \mathrm{D}$ $\left[\mathrm{Zn}_{2} \mathrm{~L}_{3}\right]^{+}$(633); $\mathrm{E}\left[\mathrm{HgZnL}_{3}\right]^{+}(767)$; and $\mathrm{F}\left[\mathrm{HgZn}_{2} \mathrm{~L}_{4} \mathrm{X}\right]^{+}$(1099). Calculated (top) and observed (bottom) isotope pattern for (b) $\left[\mathrm{HgZn}_{2} \mathbf{L}_{4}\right]^{2+}$ and (c) $\left[\mathrm{HgZn}_{2} \mathbf{L}_{4} \mathrm{ClO}_{4}\right]^{+}$.

Significantly, the three ions with $\mathrm{Zn} / \mathrm{L}<1$ that were observed for 1c became undetectable with as little as 0.5 equiv of added 
$\mathrm{Hg}$ (II) (Figure 20), and monometallic ions became prevalent (Figure S10), including a disulfide complex $\left[\mathrm{Zn}(\mathbf{L}-\mathbf{L}) \mathrm{ClO}_{4}\right]^{+}$

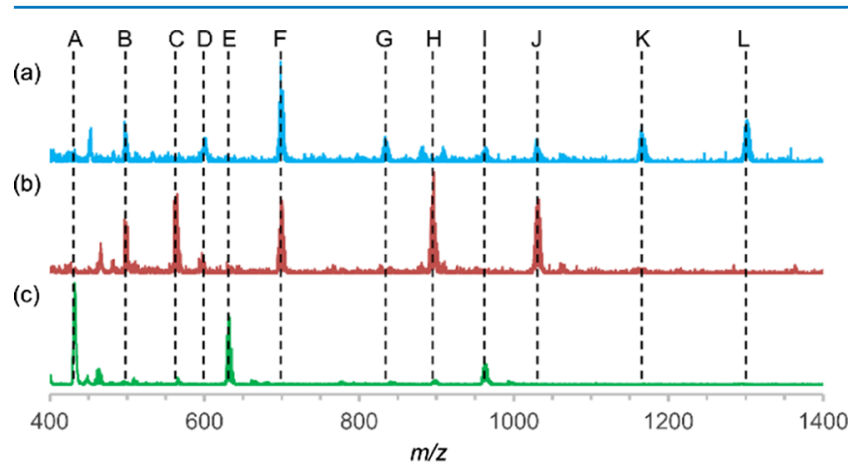

Figure 20. ESI-MS highlights of $\left[\mathrm{Zn}_{3} \mathrm{~L}_{4}\left(\mathrm{ClO}_{4}\right)_{2}\right] \cdot 2 \mathrm{CH}_{3} \mathrm{CN}$ (1c) titrated with $\mathrm{Hg}\left(\mathrm{ClO}_{4}\right)_{2}$. (a) $1: 1 \quad \mathbf{1 c} / \mathrm{Hg}\left(\mathrm{ClO}_{4}\right)_{2}$, (b) $1: 0.5 \quad 1 \mathrm{c} /$ $\mathrm{Hg}\left(\mathrm{ClO}_{4}\right)_{2}$, and (c) 1c. Labeled ion assignments with $\mathrm{X}=\mathrm{ClO}_{4}{ }^{-}$ (highest intensity $\mathrm{m} / z$ ): $\mathrm{A}\left[\mathrm{Zn}_{3} \mathbf{L}_{4}\right]^{2+}(432) ; \mathrm{B}[\mathrm{Zn}(\mathbf{L}-\mathbf{L}) \mathrm{X}]^{+}(500)$ (Figure S11); C $\left[\mathrm{Zn}_{2} \mathbf{L}_{2} \mathrm{X}\right]^{+}(565) ; \mathrm{D}\left[\mathrm{Hg}_{3} \mathbf{L}_{3} \mathrm{X}\right]^{2+}(601) ; \mathrm{E}\left[\mathrm{Zn}_{2} \mathbf{L}_{3}\right]^{+}$ (633); F $\left[\mathrm{HgZnL}_{2} \mathrm{X}\right]^{+}(699) ; \mathrm{G}\left[\mathrm{Hg}_{2} \mathrm{~L}_{2} \mathrm{X}\right]^{+}(835) ; \mathrm{H}\left[\mathrm{Zn}_{3} \mathbf{L}_{3} \mathrm{X}_{2}\right]^{+}$ (897); I $\left[\mathrm{Zn}_{3} \mathbf{L}_{4} \mathrm{X}\right]^{+}$(963); J $\left[\mathrm{HgZn}_{2} \mathbf{L}_{3} \mathrm{X}_{2}\right]^{+}$(1032); $\mathrm{K}\left[\mathrm{HgZn}_{2} \mathbf{L}_{5}\right]^{+}$ (1167); and $\mathrm{L}\left[\mathrm{Hg}_{3} \mathrm{~L}_{3} \mathrm{X}_{2}\right]^{+}(1303)$. Lower $m / z$ peaks for monometallic complexes are omitted (Figure S10).

assigned to $m / z 500$ based on the observed charge and isotope pattern (Figure S11). The most prevalent multimetallic species detected with up to 2 equiv of $\mathrm{Hg}\left(\mathrm{ClO}_{4}\right)_{2}$ added to 1 had general compositions $\left[\mathrm{M}_{2} \mathrm{~L}_{2} \mathrm{ClO}_{4}\right]^{+}$and $\left[\mathrm{M}_{3} \mathrm{~L}_{3}\left(\mathrm{ClO}_{4}\right)_{2}\right]^{+}$, and neither $\left[\mathrm{HgZn}_{2} \mathbf{L}_{4}\right]^{2+}$ nor $\left[\mathrm{HgZn}_{2} \mathbf{L}_{4} \mathrm{ClO}_{4}\right]^{+}$were evident. On the basis of these observations, indirect preparation of $\mathbf{2}$ from $\mathbf{1}$ and $\mathrm{Hg}\left(\mathrm{ClO}_{4}\right)_{2}$ was not attempted.

Our efforts to monitor metal ion redistribution by ESI-MS were repeated with precipitated $\left[\mathrm{HgL}\left(\mathrm{ClO}_{4}\right)_{2}\right]$ (3). This experiment was expected to provide better thermodynamic conditions for the desired metal exchange process. Furthermore, parallels to the metallothionein metal exchange process were enhanced because the abundance of metal-coordinating molecules in the biological milieu keeps the concentration of solvated metal ions very low. In this experiment, the peaks assigned to $\left[\mathrm{Zn}_{3} \mathbf{L}_{4}\right]^{2+}$ and $\left[\mathrm{Zn}_{3} \mathbf{L}_{4}\left(\mathrm{ClO}_{4}\right)_{2}\right]^{+}$lost intensity as the ratio of 3 to 1 was increased (Figure 21). Ions associated with 2 became prevalent with $1-2$ equiv of added 3 rather than the monometallic species. In addition to ions with the general compositions $\left[\mathrm{M}_{2} \mathrm{~L}_{2} \mathrm{ClO}_{4}\right]^{+}$and $\left[\mathrm{M}_{3} \mathrm{~L}_{3}\left(\mathrm{ClO}_{4}\right)_{2}\right]^{+}$, a peak assigned to $\left[\mathrm{Hg}_{2} \mathrm{ZnL}_{4} \mathrm{ClO}_{4}\right]^{+}(m / z$ 1235) was also observed, suggesting that two $\mathrm{Zn}$ (II) in 1 could be replaced by $\mathrm{Hg}$ (II) (Figure S12a). Significantly, a meridional octahedral $\mathrm{HgL}_{2}$ site was previously observed in pentametallic $4 .^{30}$ Furthermore, the chemically induced dissociation pattern for the isolated ion was consistent with processes 5 and 6 (Figure S12b).

$$
\begin{aligned}
& {\left[\mathrm{Hg}_{2} \mathrm{ZnL}_{4} \mathrm{ClO}_{4}\right]^{+} \rightarrow\left[\mathrm{ZnLClO}_{4}\right]+\left[\mathrm{Hg}_{2} \mathbf{L}_{3}\right]^{+}} \\
& {\left[\mathrm{Hg}_{2} \mathrm{ZnL}_{4} \mathrm{ClO}_{4}\right]^{+} \rightarrow\left[\mathrm{HgL}_{2}\right]+\left[\mathrm{HgZnL}_{2} \mathrm{ClO}_{4}\right]^{+}}
\end{aligned}
$$

Observation of two fragmentation pathways is consistent with the location of mercury in both terminal and central positions, further documenting the facile replacement of $\mathrm{Zn}$ (II) by $\mathrm{Hg}$ (II) in thiolate-rich clusters.

\section{CONCLUSIONS}

A solvomorphic series of alkylthiolate-bridged $\mathrm{HgZn}_{2}$ complexes with parallels to the metal clusters associated with

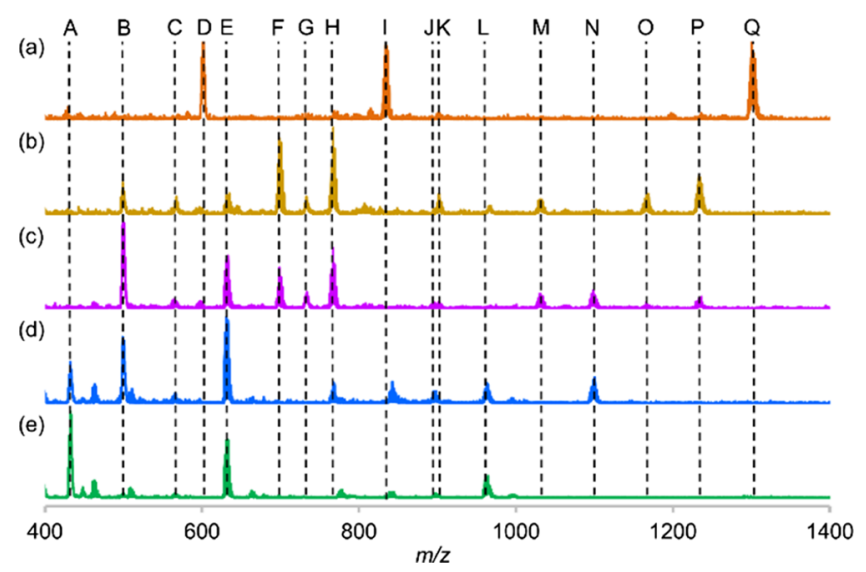

Figure 21. ESI-MS highlights of $\left[\mathrm{Zn}_{3} \mathbf{L}_{4}\left(\mathrm{ClO}_{4}\right)_{2}\right] \cdot 2 \mathrm{CH}_{3} \mathrm{CN}$ (1c), $\left[\mathrm{HgL}\left(\mathrm{ClO}_{4}\right)\right]$ (3), and mixtures of the two. (a) 3, (b) 1:0.5 1c/3, (c) $1: 2 \mathrm{1c} / 3$, (d) $1: 3 \mathrm{1c} / 3$, and (e) 1c. Labeled ion assignments with $\mathrm{X}=$ $\mathrm{ClO}_{4}{ }^{-}$(highest intensity $\mathrm{m} / z$ ): $\mathrm{A}\left[\mathrm{Zn}_{3} \mathbf{L}_{4}\right]^{2+}(432) ; \mathrm{B}\left[\mathrm{HgZn}_{2} \mathbf{L}_{4}\right]^{2+}$ (500); C $\left[\mathrm{Zn}_{2} \mathbf{L}_{2} \mathrm{X}\right]^{+}$(565); D $\left[\mathrm{Hg}_{3} \mathbf{L}_{3} \mathrm{X}\right]^{2+}$ (601); E $\left[\mathrm{Zn}_{2} \mathbf{L}_{3}\right]^{+}$(633); $\mathrm{F}$ $\left[\mathrm{HgZnL}_{2} \mathrm{X}\right]^{+}$(699); G unassigned (733); $\mathrm{H}\left[\mathrm{HgZnL}_{3}\right]^{+}$(767); I $\left[\mathrm{Hg}_{2} \mathbf{L}_{2} \mathrm{X}\right]^{+}$(835); J $\left[\mathrm{Zn}_{3} \mathbf{L}_{3} \mathrm{X}_{2}\right]^{+}$(897); $\mathrm{K}\left[\mathrm{Hg}_{2} \mathbf{L}_{3}\right]^{+}$(903); L $\left[\mathrm{Zn}_{3} \mathbf{L}_{4} \mathrm{X}\right]^{+}$(963); M $\left[\mathrm{HgZn}_{2} \mathbf{L}_{3} \mathrm{X}_{2}\right]^{+}(1032) ; \mathrm{N}\left[\mathrm{HgZn}_{2} \mathbf{L}_{4} \mathrm{X}\right]^{+}$ (1099); $\mathrm{O}\left[\mathrm{HgZn}_{2} \mathrm{~L}_{5}\right]^{+}(1167) ; \mathrm{P}\left[\mathrm{Hg}_{2} \mathrm{ZnL}_{4} \mathrm{X}\right]^{+}$(1235); and $\mathrm{Q}$ $\left[\mathrm{Hg}_{3} \mathbf{L}_{3} \mathrm{X}_{2}\right]^{+}(1303)$. Lower $\mathrm{m} / z$ peaks for monometallic complexes are omitted.

metallothionein are reported. Complexes with $\left[\mathrm{Hg}(\mathrm{ZnL})_{2}\right]^{2+}$ complex cations were prepared either directly from $\mathrm{Hg}$ (II) and $\mathrm{Zn}$ (II) perchlorate salts, ligand, and base or indirectly from the homometallic $\left[\mathrm{Zn}(\mathrm{ZnL})_{2}\right]\left(\mathrm{ClO}_{4}\right)_{2}$ complex and $\left[\mathrm{HgLClO}_{4}\right]$. A pair of pseudoisomorphic $\mathrm{Zn}_{3}$ and $\mathrm{HgZn}_{2}$ complexes crystallizing in the space group $I \overline{4}$ confirmed that very modest structural changes are necessary to accommodate metal substitution at a thiolate-bridged site. The interplay of hydrogen bonding and aromatic-packing interactions in bringing lamellar, 2D lamellar, and columnar arrangements of complex cations in the crystalline state is evaluated. Solid-state studies were complemented by variable temperature solution proton NMR and gas-phase ESI-MS studies, suggesting that both $\left[\mathrm{Zn}_{3} \mathbf{L}_{4}\right]^{2+}$ and $\left[\mathrm{HgZn}_{2} \mathbf{L}_{4}\right]^{2+}$ remained largely intact in solution at nominally millimolar concentrations. We believe these findings will be helpful in designing additional thiolatebridged clusters modeling the complexity of the metal interaction with metallothionein.

\section{EXPERIMENTAL METHODS}

4.1. Materials and General Methods. Organic solvents and reagents were of commercial grade and used as received. Metal salts were dried under vacuum overnight. Capillary melting points were obtained using a Mel-Temp apparatus and are uncorrected. Elemental analyses were performed by Atlantic Microlab, Inc. of Norcross, GA.

CAUTION! The perchlorate complexes included in this work were stable for routine synthesis and purification procedures. However, caution should be exercised because perchlorate salts of metal complexes with organic ligands are potentially explosive. ${ }^{46,47}$

4.2. Instrumental Methods. 4.2.1. X-ray Crystallography. Single crystals were harvested and then attached to a glass fiber. Data were collected on a Bruker AXS three-circle APEX DUO diffractometer equipped with a SMART APEX II CCD detector using $\varphi$ and $\omega$ scans. The X-ray source used was either a $\mathrm{Cu} \mathrm{K} \alpha$ 


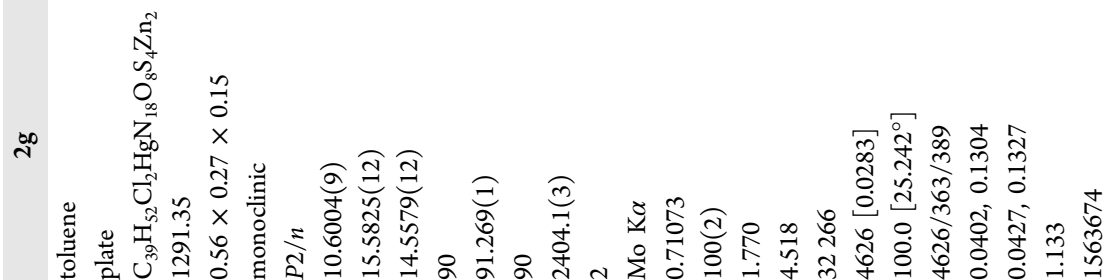

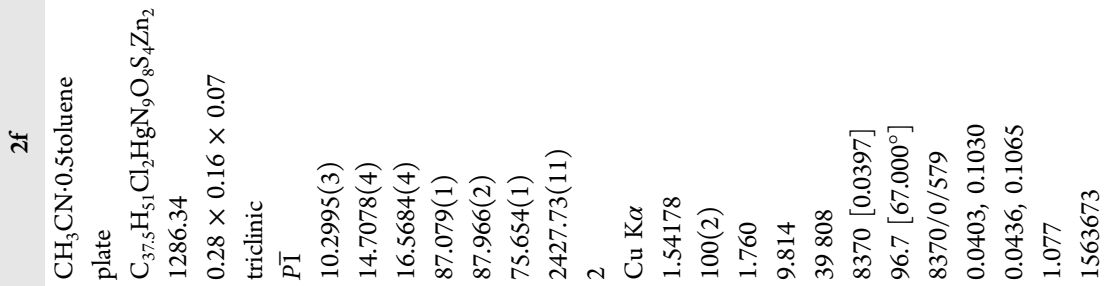

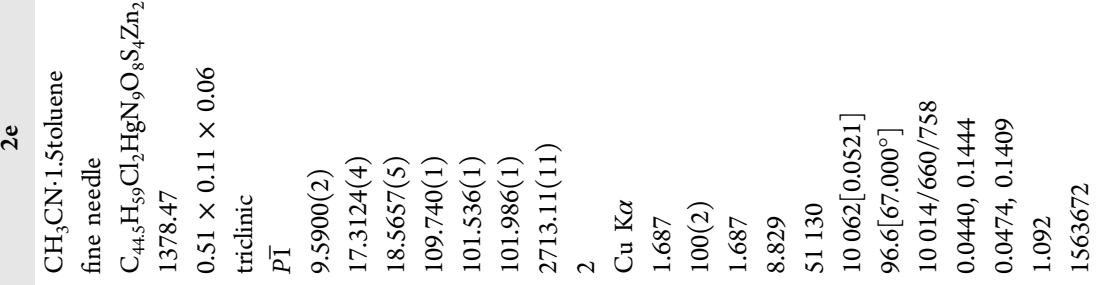

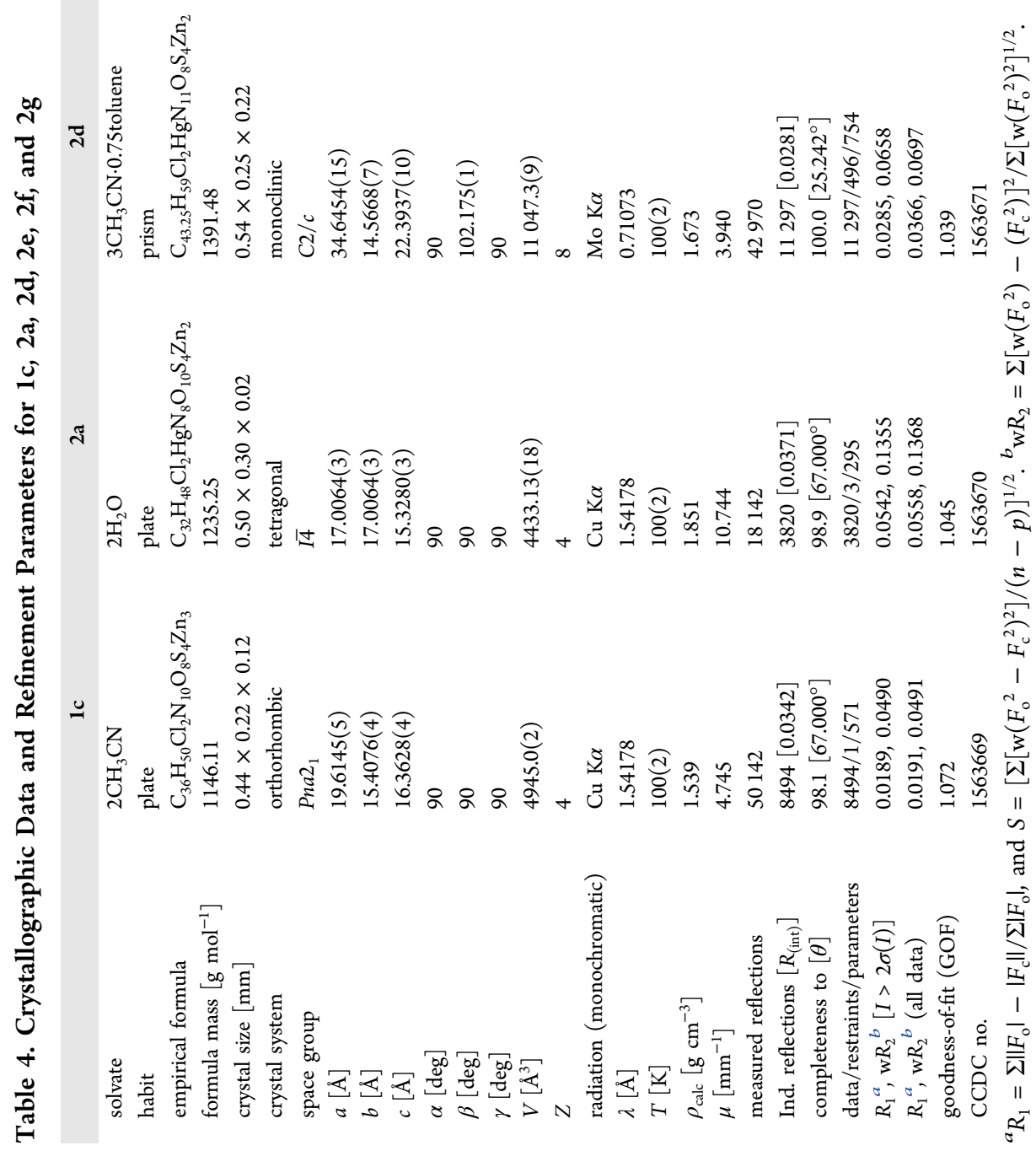


fine focus sealed tube (1c, $2 \mathrm{a}$, and $\mathbf{2 f}$ ), $\mathrm{Cu} \mathrm{K} \alpha$ microfocus sealed tube $(2 \mathrm{e})(\lambda=1.54178 \AA)$, or Mo $\mathrm{K} \alpha$ fine focus sealed tube $(\lambda=0.71073 \AA)(2 \mathrm{~g}$ and $2 \mathrm{~d})$. SADABS was then used to correct the collected data for Lorentz and polarization effects in addition to absorption. Intrinsic phasing was used to solve the structures. $^{48}$ Refinements were made using SHELXL, ${ }^{49}$ ShelXle, ${ }^{50}$ and Olex ${ }^{51}$ software. Additionally, all nonhydrogen atoms were refined anisotropically, whereas the hydrogen atomic positions on the bonded carbons were fixed isotropically with regard to thermal parameters. To model the solvent disorder in $\mathbf{2 d}$, occupancies were refined, and then some were fixed. Selected crystallographic data are given in Table 4. Selected structural parameters are summarized in Tables 2 and 3. Mercury 3.9 was used to generate packing diagrams. ${ }^{52}$

4.2.2. Powder Diffraction. Powder diffraction analysis was carried out on the instrument described above. Samples were ground and prepared as mulls using Parabar 10312 oil. Three $180 \mathrm{~s}$ frames were collected, covering $2 \theta$ of $8^{\circ}-70^{\circ}$. Frames were merged using the SMART APEX II software ${ }^{53}$ and were further processed using DIFFRAC-Plus and EVA software. ${ }^{54}$

4.2.3. Solution Proton NMR. Proton NMR spectra were collected in $5 \mathrm{~mm}$ outside diameter NMR tubes on an Agilent 400MR DD2 NMR spectrometer operating in the pulse Fourier transform mode. Calibrated autopipettes were used to prepare solutions that were nominally $2-5 \mathrm{mM}$ for variable temperature NMR measurements by dissolution of elementally analyzed complexes. The sample temperature was maintained by blowing chilled nitrogen over the NMR tube in the probe. Proton chemical shifts were measured relative to the internal solvent but are reported relative to tetramethylsilane. Coupling constants are reported in hertz. Line-fitting analyses were performed with Acorn NMR Utility Transform Software. ${ }^{55}$

4.2.4. ESI-MS. ESI-MS spectra were obtained on a LCQDECA ion trap mass spectrometer (Thermo) equipped with an ESI source. Dilute solutions (nominally $5 \times 10^{-4} \mathrm{M}$ ) in acetonitrile were directly infused into the ESI source at a flow rate of $10 \mu \mathrm{L} / \mathrm{min}$. Ion-focusing conditions were optimized to maximize the ion signal while maintaining a capillary voltage as low as possible to minimize dissociation of metal/ligand complexes upon ionization and transfer to the ion trap. Similar ionization conditions routinely produce intact noncovalent cluster ions in our instrument. MS/MS spectra were obtained by isolating the parent ion at $q_{z}=0.250$, with isolation widths adjusted to isolate the entire isotopic distribution of the complex. Parent ions are allowed to undergo collision-induced dissociation with the background helium buffer gas at various activation amplitudes in the range of $10-30 \%$ (normalized collision energy). Spectra were recorded in the positive ion mode. No ions were detected in the negative ion mode. Reported assignments were based on both qualitative isotope pattern matching ${ }^{56}$ and collision-induced dissociation patterns.

4.3. Syntheses and Crystal Preparation. 4.3.1. Preparation of $\mathrm{N}$-(2-Mercaptoethyl)picolylamine (L). Literature procedures were used to prepare $\mathbf{L}^{32}$ Colorless distilled $\mathbf{L}$ was stored in the refrigerator and handled under argon to limit air oxidation. ${ }^{1} \mathrm{H}$ NMR $\left(\mathrm{CD}_{3} \mathrm{CN}\right): \delta 8.495(\mathrm{~d}, 1 \mathrm{H}, J=4.7 \mathrm{~Hz}$, $\mathrm{H}_{\mathrm{a}}$ ), 7.689 (ddd, $\left.1 \mathrm{H}, J=7.9,7.9 \mathrm{~Hz},{ }^{4} J_{\mathrm{HH}}=1.5 \mathrm{~Hz}, \mathrm{H}_{\mathrm{c}}\right), 7.365$ $\left(\mathrm{d}, 1 \mathrm{H}, J=7.9 \mathrm{~Hz}, \mathrm{H}_{\mathrm{d}}\right), 7.185\left(\mathrm{dd}, 1 \mathrm{H}, J=7.6,5.0 \mathrm{~Hz}, \mathrm{H}_{\mathrm{b}}\right)$, $3.831\left(\mathrm{~s}, 2 \mathrm{H}, \mathrm{H}_{\mathrm{e}}\right), 2.767\left(\mathrm{~s}, 2 \mathrm{H}, J=6.5, \mathrm{H}_{\mathrm{g}}\right), 2.612(\mathrm{~s}, 2 \mathrm{H}, J=$ $\left.7.9, \mathrm{H}_{\mathrm{h}}\right)$.

4.3.2. Preparation of $\left[\mathrm{Zn}\left(\mathrm{ZnL}_{2}\right)_{2}\right]\left(\mathrm{ClO}_{4}\right)_{2}$ (1). A precipitate of 1 was prepared in quantitative yield by the Brand \& Vahrenkamp method. ${ }^{32} \mathrm{mp} 200{ }^{\circ} \mathrm{C}$ (dec.). ${ }^{1} \mathrm{H}$ NMR (nominally $2 \mathrm{mM}, \mathrm{CD}_{3} \mathrm{CN}, 20{ }^{\circ} \mathrm{C}$ ): $\delta 8.070(\mathrm{~d}, 1 \mathrm{H}, J=4.9$ $\left.\mathrm{Hz}, \mathrm{H}_{\mathrm{a}}\right), 7.949\left(\mathrm{ddd}, 1 \mathrm{H}, J=7.8,7.8 \mathrm{~Hz},{ }^{4} \mathrm{~J}_{\mathrm{HH}}=1.3 \mathrm{~Hz}, \mathrm{H}_{\mathrm{c}}\right.$ ), $7.517\left(\mathrm{~d}, 1 \mathrm{H}, J=7.7 \mathrm{~Hz}, \mathrm{H}_{\mathrm{d}}\right), 7.344(\mathrm{dd}, 1 \mathrm{H}, J=7.8,5.5 \mathrm{~Hz}$, $\left.\mathrm{H}_{\mathrm{b}}\right), 4.428\left(\mathrm{dd}, 1 \mathrm{H}, J=5.1 \mathrm{~Hz},{ }^{2} J=15.5 \mathrm{~Hz}, \mathrm{H}_{\mathrm{e}}\right), 4.001(\mathrm{dd}$, $\left.1 \mathrm{H}, J=11.8 \mathrm{~Hz},{ }^{2} J=14.8 \mathrm{~Hz}, \mathrm{H}_{\mathrm{e}^{\prime}}\right), 3.5-3.3\left(\mathrm{~m}, 2 \mathrm{H}, \mathrm{H}_{\mathrm{g}}, \mathrm{H}_{\mathrm{f}}\right)$, 3.052 (dddd, $1 \mathrm{H}, J=12.0,12.0,12.0,3.3 \mathrm{~Hz}, \mathrm{H}_{\mathrm{g}^{\prime}}$ ), 2.969 (d, $\left.1 \mathrm{H}, J=13.8 \mathrm{~Hz}, \mathrm{H}_{\mathrm{h}^{\prime}}\right), 2.495(\mathrm{ddd}, 1 \mathrm{H}, J=13.3,13.3,3.2 \mathrm{~Hz}$, $\mathrm{H}_{\mathrm{h}}$ ). Anal. Calcd for $\mathrm{C}_{32} \mathrm{H}_{44} \mathrm{Cl}_{2} \mathrm{~N}_{8} \mathrm{O}_{8} \mathrm{~S}_{4} \mathrm{Zn}_{3}: \mathrm{C}, 36.11 ; \mathrm{H}, 4.17$; N, 10.54. Found: C, 36.27; H, 4.20; N, 10.49\%.

4.3.3. Preparation of $\left[\mathrm{Zn}\left(\mathrm{ZnL}_{2}\right)_{2}\right]\left(\mathrm{ClO}_{4}\right)_{2} \cdot 2 \mathrm{CH}_{3} \mathrm{CN}$ (1c). Recrystallization of $1(50 \mathrm{mg}, 44 \mu \mathrm{mol})$ from acetonitrile/ toluene by slow evaporation provided $1 \mathrm{c}(8.4 \mathrm{mg}, 7.3 \mu \mathrm{mol})$. NMR is identical to that of 1 . Homogeneity of crystalline material was confirmed by powder X-ray diffraction (PXRD) (Figure S1). mp $177{ }^{\circ} \mathrm{C}$ (dec.). Anal. Calcd for $\mathrm{C}_{36} \mathrm{H}_{50} \mathrm{Cl}_{2} \mathrm{~N}_{10} \mathrm{O}_{8} \mathrm{~S}_{4} \mathrm{Zn}_{3}: \mathrm{C}, 37.72 ; \mathrm{H}, 4.40 ; \mathrm{N}, 12.23$. Found: C, $37.91 ; \mathrm{H}, 4.44 ; \mathrm{N}, 12.20 \%$.

4.3.4. Preparation of $\left[\mathrm{Hg}\left(\mathrm{ZnL}_{2}\right)_{2}\right]\left(\mathrm{ClO}_{4}\right)_{2}$ (2). A mixture of $\mathrm{Zn}\left(\mathrm{ClO}_{4}\right)_{2} \cdot 6 \mathrm{H}_{2} \mathrm{O}(485 \mathrm{mg}, 1.3 \mathrm{mmol})$ and $\mathrm{Hg}\left(\mathrm{ClO}_{4}\right)_{2} \cdot 3 \mathrm{H}_{2} \mathrm{O}$ $(295 \mathrm{mg}, 0.65 \mathrm{mmol})$ in $15 \mathrm{~mL}$ of water was added dropwise over $30 \mathrm{~min}$ to a solution of $\mathrm{NaOH}(100 \mathrm{mg}, 2.6 \mathrm{mmol})$ and $\mathrm{L}$ (436 mg, $2.6 \mathrm{mmol})$ in $40 \mathrm{~mL}$ of water. A white solid started forming about halfway through addition of the metal mixture. The suspension was stirred briefly. A white solid was collected by vacuum filtration and dried under vacuum overnight. The anhydrous precipitate was amorphous. A crystalline phase with the powder pattern matching that of $\mathbf{2 a}$ coprecipitated in some preps (Figure S2). ${ }^{1} \mathrm{H}$ NMR (nominally $2 \mathrm{mM}, \mathrm{CD}_{3} \mathrm{CN}, 20$ $\left.{ }^{\circ} \mathrm{C}\right): \delta 8.085\left(\mathrm{~m}, 1 \mathrm{H}, \mathrm{H}_{\mathrm{a}}\right), 7.953\left(\mathrm{dd}, 1 \mathrm{H}, J=7.8,7.8 \mathrm{~Hz}, \mathrm{H}_{\mathrm{c}}\right)$, $7.519\left(\mathrm{~d}, 1 \mathrm{H}, J=7.8 \mathrm{~Hz}, \mathrm{H}_{\mathrm{d}}\right), 7.352(\mathrm{dd}, 1 \mathrm{H}, J=7.8,5.0 \mathrm{~Hz}$, $\left.\mathrm{H}_{\mathrm{b}}\right), 4.421\left(\mathrm{dd}, 1 \mathrm{H}, J=4.4 \mathrm{~Hz},{ }^{2} J=15.2 \mathrm{~Hz}, \mathrm{H}_{\mathrm{e}}\right), 4.015(\mathrm{dd}$, $\left.1 \mathrm{H}, J=11.7 \mathrm{~Hz},{ }^{2} J=14.7 \mathrm{~Hz}, \mathrm{H}_{\mathrm{e}^{\prime}}\right), 3.5-3.3\left(\mathrm{~m}, 2 \mathrm{H}, \mathrm{H}_{\mathrm{g}}, \mathrm{H}_{\mathrm{f}}\right)$, 3.1-2.9 (m, 2H, $\left.\mathrm{H}_{\mathrm{g}^{\prime}}, \mathrm{H}_{\mathrm{h}^{\prime}}\right), 2.8-2.6\left(\mathrm{~m}, 1 \mathrm{H}, \mathrm{H}_{\mathrm{h}}\right)$. Yield $426 \mathrm{mg}$ (354 $\mu \mathrm{mol}, 54 \%)$. Anal. Calcd for the anhydrate $\mathrm{C}_{32} \mathrm{H}_{44} \mathrm{Cl}_{2} \mathrm{HgN}_{8} \mathrm{O}_{8} \mathrm{~S}_{4} \mathrm{Zn}_{2}: \mathrm{C}, 32.04 ; \mathrm{H}, 3.70 ; \mathrm{N}, 9.35$. Found: C, 31.97; H, 3.76; N, 9.19\%.

4.3.5. Preparation of $\left[\mathrm{Hg}\left(\mathrm{ZnL}_{2}\right)_{2}\right]\left(\mathrm{ClO}_{4}\right)_{2} \cdot 2 \mathrm{H}_{2} \mathrm{O}$ (2a). Recrystallization of precipitate $2(50 \mathrm{mg}, 40 \mu \mathrm{mol})$ from acetonitrile/toluene by slow evaporation initially provided colorless plates of $2 \mathrm{a}$. Yield: $15 \mathrm{mg}(12 \mu \mathrm{mol}, 30 \%)$ mp 179 ${ }^{\circ} \mathrm{C}$ (dec.). NMR was indistinguishable from that of 2 . Homogeneity of crystalline material was confirmed by PXRD (Figure S2). Anal. Calcd for $\mathrm{C}_{32} \mathrm{H}_{48} \mathrm{Cl}_{2} \mathrm{HgN}_{8} \mathrm{O}_{10} \mathrm{~S}_{4} \mathrm{Zn}_{2}$ : C, 31.12; H, 3.92; N, 9.07. Found: C, 31.05; H, 3.92; N, 8.95\%.

4.3.6. Preparation of $\left[\mathrm{Hg}\left(\mathrm{ZnL}_{2}\right)_{2}\right]\left(\mathrm{ClO}_{4}\right)_{2} \cdot 3 \mathrm{CH}_{3} \mathrm{CN} \cdot 0.75 \mathrm{Tol}$ uene $(\mathbf{2 d})$. Colorless needles of $\mathbf{2 d}$ were obtained in trace quantities by further slow evaporation of the $\mathbf{2 a}$ mother liquor or by slow diffusion of an acetonitrile solution of $\mathbf{2}$ into toluene. The crystals were unstable to loss of the solvent, turning opaque after a short time in air. Crystals transferred to oil immediately after removal of the mother liquor had sufficient integrity for single-crystal diffraction. NMR was same as that of 2 with addition of toluene peaks.

4.3.7. Preparation of $\left[\mathrm{Hg}\left(\mathrm{ZnL}_{2}\right)_{2}\right]\left(\mathrm{ClO}_{4}\right)_{2} \cdot \mathrm{CH}_{3} \mathrm{CN} \cdot 1.5$ Toluene (2e). Very fine colorless needles of $2 \mathrm{e}$ were grown by further slow evaporation of the $\mathbf{2 d}$ mother liquor or by slow diffusion of an acetonitrile solution of $\mathbf{2}$ into toluene. The crystal quality deteriorated rapidly upon removal of the mother liquor even with immediate transfer to oil. NMR was same as that of 2 a with addition of toluene peaks. Anal. Calcd for $\mathrm{C}_{35.5} \mathrm{H}_{48} \mathrm{Cl}_{2} \mathrm{HgN}_{8} \mathrm{O}_{8} \mathrm{~S}_{4} \mathrm{Zn}_{2}$ (corresponding to 0.5toluene solvate): C, 34.23; H, 3.89; N, 9.00. Found: C, 34.41; H, 3.85; N, $8.83 \%$. 
4.3.8. Preparation of $\left[\mathrm{HgL}\left(\mathrm{ClO}_{4}\right)\right]$ (3). An amorphous precipitate of 3 was prepared as reported previously. ${ }^{30}{ }^{1} \mathrm{H}$ NMR (nominally $2 \mathrm{mM}, \mathrm{CD}_{3} \mathrm{CN}, 20^{\circ} \mathrm{C}$ ): $\delta 8.58(\mathrm{~d}, 1 \mathrm{H}, J=5$ $\mathrm{Hz}, \mathrm{H}_{\mathrm{a}}$ ), 8.03 (dd, $\left.1 \mathrm{H}, J=8,8 \mathrm{~Hz}, \mathrm{H}_{\mathrm{c}}\right), 7.60(\mathrm{dd}, 1 \mathrm{H}, J=8,5$ $\left.\mathrm{Hz}, \mathrm{H}_{\mathrm{b}}\right), 7.55\left(\mathrm{~d}, 1 \mathrm{H}, J=8 \mathrm{~Hz}, \mathrm{H}_{\mathrm{d}}\right), 4.33\left(\right.$ br s, $3 \mathrm{H}, \mathrm{H}_{\mathrm{e}}, \mathrm{H}_{\mathrm{e}}$ ), $3.24\left(\mathrm{~m}, 4 \mathrm{H}, \mathrm{H}_{\mathrm{g}}, \mathrm{H}_{\mathrm{g}}\right)$. Anal. Calcd for $\mathrm{C}_{8} \mathrm{H}_{11} \mathrm{ClHgN}_{2} \mathrm{O}_{4} \mathrm{~S}: \mathrm{C}$, 20.56; H, 2.37; N, 5.99. Found: C, 20.82; H, 2.33; N, 6.00\%.

4.3.9. Preparation of $\left[\mathrm{Hg}\left(\mathrm{ZnL}_{2}\right)_{2}\right]\left(\mathrm{ClO}_{4}\right)_{2} \cdot \mathrm{CH}_{3} \mathrm{CN} \cdot 0.5$ Toluene (2f). An acetonitrile solution of $\mathbf{1}(33 \mathrm{mg}, 31 \mu \mathrm{mol})$ was mixed with an acetonitrile solution of $3(15 \mathrm{mg}, 32 \mu \mathrm{mol})$ and diluted with toluene for slow evaporation. Colorless X-ray quality plates of $\mathbf{2} \mathbf{f}$ and $\mathbf{1 c}$ cocrystallized in low yield. Morphological differences between the crystals were insufficient for manual separation.

4.3.10. Preparation of $\left[\mathrm{Hg}\left(\mathrm{ZnL}_{2}\right)_{2}\right]\left(\mathrm{ClO}_{4}\right)_{2}$. Toluene (2g). A $1: 1$ acetonitrile solution of $1(33 \mathrm{mg}, 31 \mu \mathrm{mol})$ and $3(13 \mathrm{mg}$, $32 \mu \mathrm{mol})$ was slowly diffused into toluene. Colorless X-ray quality plates of $\mathbf{2 f}, \mathbf{2 g}$, and $\mathbf{1 c}$ cocrystallized in low yield. Morphological differences between $\mathbf{2 f}$ and $\mathbf{2 g}$ were insufficient for bulk separation.

\section{ASSOCIATED CONTENT}

\section{S Supporting Information}

The Supporting Information is available free of charge on the ACS Publications website at DOI: 10.1021/acsomega.7b01087.

Calculated and experimental PXRD patterns; line-fitting of proton NMR spectra; calculated and experimental ESI-MS spectra for selected ions; and MS/MS spectra for selected ions (PDF)

Crystallographic data for compounds $\mathbf{1 c}, \mathbf{2 a}, \mathbf{2 d}, \mathbf{2 e}, \mathbf{2 f}$, and $\mathbf{2 g}$ (CIF)

\section{Accession Codes}

CCDC 1563669-1563674 contain the supplementary crystallographic data for this paper. These data can be obtained free of charge via www.ccdc.cam.ac.uk/data request/cif, or by emailing data_request@ccdc.cam.ac.uk, or by contacting The Cambridge Crystallographic Data Centre, 12 Union Road, Cambridge CB2 1EZ, UK; fax: +44 1223336033.

\section{AUTHOR INFORMATION}

\section{Corresponding Author}

*E-mail: dcbebo@wm.edu. Phone: +1(757) 221-2558. Fax: $+1(757) 221-2715$ (D.C.B.).

\section{ORCID 1}

John C. Poutsma: 0000-0002-0085-4079

Robert D. Pike: 0000-0002-8712-0288

Deborah C. Bebout: 0000-0001-9228-6218

\section{Present Addresses}

${ }^{\S}$ Recipharm Laboratories, 511 Davis Dr \# 100, Morrisville, NC 27560, United States (M.R.H.).

"Department of Chemistry, University of Rochester, 404 Hutchison Hall, Box 270216, Rochester, NY 14627, United States (M.D.R.)

\section{Author Contributions}

The manuscript was written through contributions of all authors. All authors have given approval to the final version of the manuscript.

Notes

The authors declare no competing financial interest.

\section{ACKNOWLEDGMENTS}

This work was supported in part by the U.S. National Science Foundation Division of Chemistry under grant 0315934. Purchases of the College of William \& Mary SMART APEX II diffractometer and Agilent NMR were also partially supported by the U.S. National Science Foundation (grants 0443345 and 1337295 , respectively). In addition, portions of this research were supported by the College of William \& Mary. We thank Prof. Hannes Schniepp for assistance with digital photography.

\section{REFERENCES}

(1) Kleespies, S. T.; Oloo, W. N.; Mukherjee, A.; Que, L. C-H Bond Cleavage by Bioinspired Nonheme Oxoiron(IV) Complexes, Including Hydroxylation of n-Butane. Inorg. Chem. 2015, 54, 5053-5064.

(2) Puri, M.; Que, L. Toward the Synthesis of More Reactive S = 2 Non-Heme Oxoiron(IV) Complexes. Acc. Chem. Res. 2015, 48, 24432452.

(3) Itoh, S. Developing Mononuclear Copper-Active-Oxygen Complexes Relevant to Reactive Intermediates of Biological Oxidation Reactions. Acc. Chem. Res. 2015, 48, 2066-2074.

(4) Friedle, S.; Reisner, E.; Lippard, S. J. Current challenges of modeling diiron enzyme active sites for dioxygen activation by biomimetic synthetic complexes. Chem. Soc. Rev. 2010, 39, 27682779.

(5) Che, C.; Huang, J. Metalloporphyrin-based oxidation systems: From biomimetic reactions to application in organic synthesis. Chem. Commun. 2009, 3996-4015.

(6) Sivanesan, D.; Kannan, S.; Thangadurai, T. D.; Jung, K.-D.; Yoon, $\mathrm{S}$. Water is a key factor to alter the structure and electrochemical properties of carboxylate-bridged dimanganese(ii) complexes. Dalton Trans. 2014, 43, 11465-11469.

(7) Costas, M. Selective C-H oxidation catalyzed by metalloporphyrins. Coord. Chem. Rev. 2011, 255, 2912-2932.

(8) Nastri, F.; Chino, M.; Maglio, O.; Bhagi-Damodaran, A.; Lu, Y.; Lombardi, A. Design and engineering of artificial oxygen-activating metalloenzymes. Chem. Soc. Rev. 2016, 45, 5020-5054.

(9) Ruckthong, L.; Zastrow, M. L.; Stuckey, J. A.; Pecoraro, V. L. A Crystallographic Examination of Predisposition versus Preorganization in de Novo Designed Metalloproteins. J. Am. Chem. Soc. 2016, 138, 11979-11988.

(10) McWilliams, S. F.; Holland, P. L. Dinitrogen Binding and Cleavage by Multinuclear Iron Complexes. Acc. Chem. Res. 2015, 48, 2059-2065.

(11) Rauchfuss, T. B. Diiron Azadithiolates as Models for the [FeFe]Hydrogenase Active Site and Paradigm for the Role of the Second Coordination Sphere. Acc. Chem. Res. 2015, 48, 2107-2116.

(12) Serrano-Plana, J.; Garcia-Bosch, I.; Company, A.; Costas, M. Structural and Reactivity Models for Copper Oxygenases: Cooperative Effects and Novel Reactivities. Acc. Chem. Res. 2015, 48, 2397-2406.

(13) Hematian, S.; Garcia-Bosch, I.; Karlin, K. D. Synthetic Heme/ Copper Assemblies: Toward an Understanding of Cytochrome $c$ Oxidase Interactions with Dioxygen and Nitrogen Oxides. Acc. Chem. Res. 2015, 48, 2462-2474.

(14) Dalle, K. E.; Meyer, F. Modelling Binuclear Metallobiosites: Insights from Pyrazole-Supported Biomimetic and Bioinspired Complexes. Eur. J. Inorg. Chem. 2015, 3391-3405.

(15) Isani, G.; Carpenè, E. Metallothioneins, Unconventional Proteins from Unconventional Animals: A Long Journey from Nematodes to Mammals. Biomolecules 2014, 4, 435-457.

(16) Blindauer, C. A.; Leszczyszyn, O. I. Metallothioneins: unparalleled diversity in structures and functions for metal ion homeostasis and more. Nat. Prod. Rep. 2010, 27, 720-741.

(17) Robbins, A. H.; McRee, D. E.; Williamson, M.; Collett, S. A.; Xoung, N. H.; Furey, W. F.; Wang, B. C.; Stout, C. D. Refined crystal structure of $\mathrm{Cd}, \mathrm{Zn}$ metallothionein at $2.0 \AA$ resolution. J. Mol. Biol. 1991, 221, 1269-1293. 
(18) Arseniev, A.; Schultze, P.; Wörgötter, E.; Braun, W.; Wagner, G.; Vašák, M.; Kägi, J. H. R.; Wüthrich, K. Three-dimensional structure of rabbit liver $\left[\mathrm{Cd}_{7}\right]$ metallothionein-2a in aqueous solution determined by nuclear magnetic resonance. J. Mol. Biol. 1988, 201, 637-657.

(19) Schultze, P.; Wörgötter, E.; Braun, W.; Wagner, G.; Vašák, M.; Kägi, J. H. R.; Wüthrich, K. Conformation of [Cd7]-metallothionein-2 from rat liver in aqueous solution determined by nuclear magnetic resonance spectroscopy. J. Mol. Biol. 1988, 203, 251-268.

(20) Braun, W.; Vasak, M.; Robbins, A. H.; Stout, C. D.; Wagner, G.; Kägi, J. H.; Wüthrich, K. Comparison of the NMR solution structure and the X-ray crystal structure of rat metallothionein-2. Proc. Natl. Acad. Sci. U.S.A. 1992, 89, 10124-10128.

(21) Chen, S.-H.; Chen, L.; Russell, D. H. Metal-Induced Conformational Changes of Human Metallothionein-2A: A Combined Theoretical and Experimental Study of Metal-Free and Partially Metalated Intermediates. J. Am. Chem. Soc. 2014, 136, 9499-9508.

(22) Irvine, G. W.; Stillman, M. J. Cadmium binding mechanisms of isolated domains of human MT isoform 1a: Non-cooperative terminal sites and cooperative cluster sites. J. Inorg. Biochem. 2016, 158, 115121.

(23) Irvine, G. W.; Pinter, T. B. J.; Stillman, M. J. Defining the metal binding pathways of human metallothionein 1a: balancing zinc availability and cadmium seclusion. Metallomics 2016, 8, 71-81.

(24) Tarasava, K.; Loebus, J.; Freisinger, E. Localization and Spectroscopic Analysis of the $\mathrm{Cu}(\mathrm{I})$ Binding Site in Wheat Metallothionein Ec-1. Int. J. Mol. Sci. 2016, 17, 371.

(25) Henkel, G.; Krebs, B. Metallothioneins: Zinc, Cadmium, Mercury, and Copper Thiolates and Selenolates Mimicking Protein Active Site Features-Structural Aspects and Biological Implications. Chem. Rev. 2004, 104, 801-824.

(26) Blindauer, C. A.; Harrison, M. D.; Parkinson, J. A.; Robinson, A. K.; Cavet, J. S.; Robinson, N. J.; Sadler, P. J. A metallothionein containing a zinc finger within a four-metal cluster protects a bacterium from zinc toxicity. Proc. Natl. Acad. Sci. U.S.A. 2001, 98, 9593-9598.

(27) Leszczyszyn, O. I.; White, C. R. J.; Blindauer, C. A. The isolated $\mathrm{Cys}_{2} \mathrm{His}_{2}$ site in EC metallothionein mediates metal-specific protein folding. Mol. BioSyst. 2010, 6, 1592-1603.

(28) Peroza, E. A.; Kaabi, A. A.; Meyer-Klaucke, W.; Wellenreuther, G.; Freisinger, E. The two distinctive metal ion binding domains of the wheat metallothionein Ec-1. J. Inorg. Biochem. 2009, 103, 342-353.

(29) Tomas, M.; Pagani, M. A.; Andreo, C. S.; Capdevila, M.; Bofill, R.; Atrian, S. His-containing plant metallothioneins: comparative study of divalent metal-ion binding by plant MT3 and MT4 isoforms. J. Biol. Inorg Chem. 2014, 19, 1149-1164.

(30) Viehweg, J. A.; Stamps, S. M.; Dertinger, J. J.; Green, R. L.; Harris, K. E.; Butcher, R. J.; Andriole, E. J.; Poutsma, J. C.; Berry, S. M.; Bebout, D. C. A Synthetic Model of $\mathrm{Hg}$ (II) Sequestration. Dalton Trans. 2010, 39, 3174-3176.

(31) Groom, C. R.; Bruno, I. J.; Lightfoot, M. P.; Ward, S. C. The Cambridge Structural Database. Acta Crystallogr., Sect. B: Struct. Sci. 2016, 72, 171-179.

(32) Brand, U.; Vahrenkamp, H. Zinc complexes of S,N ligands derived from thiazolines. Chem. Ber. 1995, 128, 787-791.

(33) Mikuriya, M.; Jian, X.; Ikemi, S.-i.; Kawahashi, T.; Tsutsumi, H. Synthesis and Structural Characterization of Thiolato-Bridged Zinc(II) Complexes with NNS-Tridentate Thiolic Ligands. Bull. Chem. Soc. Jpn. 1998, 71, 2161-2168.

(34) Brand, U.; Vahrenkamp, H. Zinc complexes of the new N,N,S ligand N-(2-mercaptoisobutyl)(picolyl)amine. Inorg. Chim. Acta 2000, 308, 97-102.

(35) Ostwald, W. Studien über die Bildung und Umwandlung fester Körper. 1. Abhandlung: Übersättigung und Überkaltung. Z. Phys. Chem. 1897, 22, 289-330.

(36) Tidey, J. P.; O’Connor, A. E.; Markevich, A.; Bichoutskaia, E.; Cavan, J. J. P.; Lawrance, G. A.; Wong, H. L. S.; McMaster, J.; Schröder, M.; Blake, A. J. Epitaxial Retrieval of a Disappearing Polymorph. Cryst. Growth Des. 2015, 15, 115-123.
(37) Capasso, C.; Carginale, V.; Crescenzi, O.; Di maro, D.; Spadaccini, R.; Temussi, P. A.; Parisi, E. Structural and functional studies of vertebrate metallothioneins: cross-talk between domains in the absence of physical contact. Biochem. J. 2005, 391, 95-103.

(38) Ngu, T. T.; Lee, J. A.; Rushton, M. K.; Stillman, M. J. Arsenic Metalation of Seaweed Fucus vesiculosus Metallothionein: The Importance of the Interdomain Linker in Metallothionein. Biochemistry 2009, 48, 8806-8816.

(39) Ninković, D. B.; Janjić, G. V.; Zarić, S. D. Crystallographic and ab Initio Study of Pyridine Stacking Interactions. Local Nature of Hydrogen Bond Effect in Stacking Interactions. Cryst. Growth Des. 2012, 12, 1060-1063.

(40) Janiak, C. A critical account on $\pi-\pi$ stacking in metal complexes with aromatic nitrogen-containing ligands. J. Chem. Soc., Dalton Trans. 2000, 3885-3896.

(41) Dance, I. $\pi-\pi$ Interactions: Theory and Scope. In Encyclopedia of Supramolecular Chemistry; Atwood, J. L., Steed, J. W., Eds.; Marcel Dekker, Inc.: New York, 2004; Vol. 2, pp 1076-1092.

(42) Johnson, C. E.; Bovey, F. A. Calculation of Nuclear Magnetic Resonance Spectra of Aromatic Hydrocarbons. J. Chem. Phys. 1958, 29, 1012-1014.

(43) Bebout, D. C.; Ehmann, D. E.; Trinidad, J. C.; Crahan, K. K.; Kastner, M. E.; Parrish, D. A. Preparation of Mercury(II) Complexes of Tris[(2-pyridyl)methyl]amine and Characterization by X-ray Crystallography and NMR Spectroscopy. Inorg. Chem. 1997, 36, 4257-4264.

(44) Bebout, D. C.; DeLanoy, A. E.; Ehmann, D. E.; Kastner, M. E.; Parrish, D. A.; Butcher, R. J. Characterization of Mercury(II) Complexes of Bis[(2-pyridyl)methyl]amine by X-ray Crystallography and NMR Spectroscopy. Inorg. Chem. 1998, 37, 2952-2959.

(45) Tice, D. B.; Pike, R. D.; Bebout, D. C. Contrasting coordination behavior of Group 12 perchlorate salts with an acyclic $\mathrm{N}_{3} \mathrm{O}_{2}$ donor ligand by X-ray crystallography and ${ }^{1} \mathrm{H}$ NMR. Dalton Trans. 2016, 45, 12871-12883.

(46) Wolsey, W. C. Perchlorate salts, their uses and alternatives. J. Chem. Educ. 1973, 50, A335.

(47) Raymond, K. N. Tragic consequence with acetonitrile adduct. Chem. Eng. News 1983, 61, 4.

(48) Sheldrick, G. M. SADABS; University of Göttingen: Göttingen, Germany, 2005.

(49) Sheldrick, G. M. A short history of SHELX. Acta Crystallogr., Sect. A: Found. Crystallogr. 2008, 64, 112-122.

(50) Hübschle, C. B.; Sheldrick, G. M.; Dittrich, B. ShelXle: a Qt graphical user interface for SHELXL. J. Appl. Crystallogr. 2011, 44, $1281-1284$

(51) Dolomanov, O. V.; Bourhis, L. J.; Gildea, R. J.; Howard, J. A. K.; Puschmann, H. OLEX2: A complete structure solution, refinement and analysis program. J. Appl. Crystallogr. 2009, 42, 339-341.

(52) Mercury 3.9 (Windows); Cambridge Crystallographic Data Centre, 2016.

(53) SMART APEX II, Data Collection Software; Bruker AXS Inc.: Madison, WI, 2005.

(54) DIFFRAC Plus, version 10.0; EVA, release 2004; Bruker AXS Inc.: Madison, WI, 2005.

(55) NUTS-NMR Utility Transform Software, 1D version for Windows 95/NT; Acorn NMR, Inc.: Livermore, CA, 1998.

(56) Yan, J. Isotope Pattern Calculator 4.0, 2001. 